\title{
1 Investigation of subglacial weathering under the Greenland Ice Sheet using
} 2 silicon isotopes.

3 J. E. Hatton ${ }^{1 *}$, K. R. Hendry ${ }^{1}$, J. R. Hawkings ${ }^{2,3,4}$, J. L. Wadham ${ }^{2}$, T. J. Kohler ${ }^{5,6}$, M. Stibal ${ }^{5}$, A. D.

4 Beaton $^{7}$, E. A. Bagshaw ${ }^{8}$. J. Telling ${ }^{9}$

$5 \quad{ }^{1}$ School of Earth Sciences, Univeristy of Bristol. (*correspondence: j.e.hatton@bristol.ac.uk)

$6 \quad{ }^{2}$ School of Geographical Sciences, Univeristy of Bristol.

$7 \quad{ }^{3}$ National High Magnetic Field Lab and Earth, Ocean and Atmospheric Sciences, Florida State

8 Universtiy, USA

$9 \quad{ }^{4}$ German Research Centre for Geosciences GFZ, Potsdam, Germany

$10{ }^{5}$ Department of Ecology, Faculty of Science, Charles University.

${ }^{6}$ Stream Biofilm and Ecosyste Research Laboratory, School of Architecture, Civil and Environmental Engineering, École Polytechnique Fédérale de Lausanne, CH-1015 Lausanne, Switzerland.

${ }^{7}$ Technology an Engineering Group, National Oceanography Centre, Southampton.

${ }^{8}$ School of Earth and Ocean Sciences, Cardiff University.

${ }^{9}$ School of Natural and Environmental Sciences, Newcastle University.

*Jade E Hatton, Bristol Glaciology Centre, School of Geographical Sciences, University of Bristol, University Road, BS8 1SS, UK (jh12528@bristol.ac.uk)

Katharine R Hendry, School of Earth Sciences, University of Bristol, Bristol, BS8 1RJ, UK

(k.hendry@bristol.ac.uk)

Jon R Hawkings, National High Magnetic Field Lab and Earth, Ocean and Atmospheric Sciences, Florida State University, Tallahassee, Florida, USA (jhawkings@fsu.edu); German Research Centre for Geosciences GFZ, Telegrafenberg, Building C, 14473, Potsdam, Germany (hawkings@gfzpotsdam.de) Jemma L Wadham, Bristol Glaciology Centre, School of Geographical Sciences, University of Bristol, University Road, BS8 1SS, UK (j.1.wadham@bristol.ac.uk)

Tyler J Kohler, Stream Biofilm and Ecosyste Research Laboratory, School of Architecture, Civil and Environmental Engineering, École Polytechnique Fédérale de Lausanne, CH-1015 Lausanne, Switzerland (tyler.j.kohler@gmail.com)

Marek Stibal, Faculty of Science, Department of Ecology, Charles University, Viničná 7, 12844

Prague 2, Prague, Czech Republic (marek.stibal@natur.cuni.cz)

Alexander Beaton, National Oceanography Centre Southampton, Waterfront Campus, European Way, Southampton, SO14 3ZH, UK (a.beaton@noc.ac.uk)

Elizabeth Bagshaw, School of Earth and Ocean Sciences, Cardiff University, Main Building, Park Place, Cardiff, CF10 3AT, UK (bagshawe@ cardiff.ac.uk)

Jon Telling, School of Natural and Environmental Sciences, Newcastle University, NE1 7RU, UK (jon.telling@newcastlea.ac.uk)

\section{Abstract}

Subglacial chemical weathering plays a key role in global silicate weathering budgets, contributing to the cycling of silicon $(\mathrm{Si})$ in terrestrial and marine systems and the potential drawdown of carbon dioxide from the atmosphere. Here, we use data from two Greenland Ice Sheet (GrIS) catchments to demonstrate how Si isotopes from dissolved and amorphous particulate fractions $\left(\delta^{30} \mathrm{DSi}\right.$ and $\delta^{30} \mathrm{ASi}$ respectively) can be used together with major ion data to assess the degree of secondary silicate weathering product formation and redissolution in subglacial environments. We compare a time-series of summer melt seasons from the two study sites, which differ in catchment size $\left(\sim 600 \mathrm{~km}^{2}\right.$ for Leverett Glacier (LG) and $\sim 36 \mathbf{k m}^{2}$ for 
$\mathrm{Ca}^{2+}$ and $\mathrm{Mg}^{2+}$ ions, indicating a predominance of silicate weathering, whilst meltwaters from KS are characterised by carbonate weathering (hydrolysis and carbonation) throughout the melt season. Both catchments have mean $\delta^{30} \mathrm{DSi}$ values substantially lower than average riverine

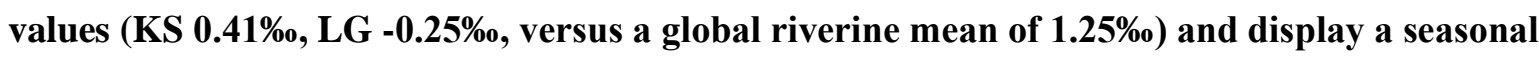
decline, which is more pronounced at LG. The $\delta^{30} \mathrm{ASi}$ values (discharge weighted mean values KS -0.44\%, LG -0.22\%) are lighter than the bedrock (mean values KS $-\mathbf{0 . 1 8} \pm \mathbf{0 . 1 2 \%}$, LG $\mathbf{0 . 0 0} \pm 0.07 \%$ ) in both catchments, indicating a secondary weathering product origin or leaching of lighter isotopes during initial weathering of crushed rock. When used in combination, the major ion and silicon isotope data reveal that the extent of silicate weathering and secondary phase redissolution are more pronounced at LG compared to KS. Contrasting weathering regimes and subglacial hydrology between catchments need to be considered when estimating the $\delta^{30} \mathrm{Si}$ composition of silica exported into polar oceans from the GrIS, with larger catchments likely to produce fluxes of lighter $\delta^{30} \mathrm{Si}$. As larger catchments dominate freshwater export to the ocean, GrIS meltwater is likely to be very light in isotopic composition, and the flux is likely to increase with ice melt as the climate warms.

\section{Introduction}

The weathering of silicate minerals plays an important role in biogeochemical cycles, producing dissolved silicate (DSi) and dissolvable amorphous silica (ASi) into terrestrial and marine systems, whilst consuming carbon dioxide $\left(\mathrm{CO}_{2}\right)$ (Walker et al., 1981; Berner, 2003). DSi is generated through physical weathering and the subsequent chemical dissolution of silicate minerals, and then mobilised via fluvial hydrological systems. Primary weathering processes also lead to secondary mineral formation. Secondary weathering products, such as clays and ASi have varying solubility and may contribute DSi to the fluvial system through redissolution processes (Frings et al., 2016). The resultant DSi is converted to biogenic silica (BSi) by siliceous organisms, including diatoms, which are responsible for 35-70\% of oceanic productivity (Nelson et al., 1995). Weathering processes, precipitation, and biogenic uptake result in fractionation of silicon isotopes, meaning isotopic analysis can provide insight into the weathering regimes and biological utilisation of $\mathrm{Si}$ within aquatic systems (De la Rocha et al., 1997; De La Rocha et al., 2000; Fontorbe et al., 2013; Frings et al., 2016).

Glaciation promotes physical and chemical weathering, with dynamic hydrological and microbial systems upon, within and beneath ice (Wadham et al., 2010; Tranter and Wadham, 2014). It is likely that weathering beneath large ice sheets is silicate mineral dominated (Stevenson et al., 2017), due to the enhanced residence times of subglacially stored waters, which result in exhaustion of carbonate minerals or saturation of meltwaters with respect to calcite (Wadham et al., 2010; Hindshaw et al., 2014; Michaud et al., 2016). This is evidenced by the ionic composition of meltwaters (high relative 
proportions of $\mathrm{Na}^{+}$and $\mathrm{K}^{+}$) from the bed of the Greenland Ice Sheet (GrIS) (Graly et al., 2014) and the Antarctic Ice Sheet (AIS) (Michaud et al., 2016) compared to Alpine valley glaciers. Recently, there has been increased focus on the chemical composition of GrIS meltwaters in an attempt to improve the understanding of weathering processes in large ice sheet catchments and associated nutrient release (Graly et al., 2014; Hindshaw et al., 2014; Yde et al., 2014; Graly et al., 2017; Kohler et al., 2017). High fluxes of Si resulting from weathering processes have been reported from ice sheets. For example, Hawkings et al. (2017) estimated silica fluxes from GrIS to be approximately 50\% of input from Arctic rivers $\left(0.20 \mathrm{Tmol} \mathrm{year}^{1}\right)$. However, the mechanisms and control on silicate dissolution processes in ice sheet catchments are currently poorly understood, which is compounded by the difficulty of acquiring data over an entire melt season and across differing hydrological regimes in challenging environments. An improved understanding of the complex nature and extent of subglacial silicate weathering is necessary to fully understand and quantify silicon cycling on a global scale (Graly et al., 2014; Hindshaw et al., 2014; Yde et al., 2014).

Silicon isotopes (denoted by $\delta^{30} \mathrm{Si}$ ) are increasingly used as a tool for studying continental weathering (Ding et al., 2004; Georg et al., 2007; Opfergelt et al., 2013; Chemtob et al., 2015), especially in riverine systems (Ding et al., 2004; Cardinal et al., 2010; Ding et al., 2011; Fontorbe et al., 2013; Frings et al., 2016). Silicon has three stable isotopes; ${ }^{28} \mathrm{Si},{ }^{29} \mathrm{Si}$ and ${ }^{30} \mathrm{Si}$ with relative abundances of $92.2 \%, 4.7 \%$ and $3.1 \%$ respectively (Ding et al., 2005). The isotopic composition is reported relative to international reference standard NBS-28, as a deviation from the ratio of ${ }^{28} \mathrm{Si} /{ }^{30} \mathrm{Si}$ of the sample from the reference standard (Equation 1, Frings et al. 2016). The isotopic composition of the lower crust $(-0.29 \pm 0.04 \%)$, middle crust $(-0.23 \pm 0.04 \%)$ and bulk earth values $(-0.29 \pm 0.08 \%)$ are well characterised (Savage et al., 2010; Savage et al., 2013). Relatively large fractionation occurs during weathering processes as newly formed secondary weathering products are enriched with lighter isotopes (Andre et al., 2006; Frings et al., 2016). The range of DSi isotopic compositions in rivers draining from non-glaciated catchments is currently 0.4-3.4\% (De La Rocha et al., 2000; Ding et al., 2004; Cardinal et al., 2010; Ding et al., 2011), with a global mean of $1.25 \pm 0.68 \%$ o (Frings et al., 2016). Riverine DSi is therefore generally enriched in the ${ }^{30} \mathrm{Si}$ isotope compared with bulk silicate earth and suspended particulate matter, which is isotopically lighter on average $(-0.18 \%$, Frings et al., 2016; Ding et al. 2004). Precipitated silica from the formation of secondary weathering or biological uptake is enriched in ${ }^{28} \mathrm{Si}$, due to preferential uptake of the lighter isotope, resulting in an enrichment of ${ }^{30} \mathrm{Si}$ in the dissolved phase (De la Rocha et al., 1997; De La Rocha et al., 2000; Ziegler et al., 2002; Ding et al., 2004). However, whilst these generalisations about the fractionation of low temperature processes can be made, more definite fractionation factors for many environmental processes are still very uncertain (Frings et al., 2016).

Studies of Icelandic rivers have shown that catchments with greater glacial coverage have a lighter dissolved $\delta^{30} \mathrm{Si}$ composition ( $\delta^{30} \mathrm{DSi}$ ) compared to non-glacial rivers (Georg et al., 2007). Opfergelt et 
al. (2013) reported glacial rivers to have a mean composition of $0.17 \pm 0.18 \%$ compared to $0.97 \pm$ $0.31 \%$ for non-glacial rivers. The dissolved phase exported from a large ice sheet catchment of GrIS has also been shown to have an isotopic composition lighter than the bulk bedrock $(-0.25 \pm 0.12 \%$ o compared to $0.00 \pm 0.07 \%$, Hawkings et al., 2018). These studies indicate that subglacial processes could be influencing the isotopic composition of meltwaters. Si isotope systematics could potentially be used to provide insight into silicate dissolution and redissolution of secondary weathering products within the subglacial environment. However, we currently lack high resolution time series data to show whether these patterns are consistent across glacial catchments and to explain the mechanism driving the export of low $\delta^{30} \mathrm{Si}$. We need to gain a better understanding of subglacial biogeochemical processes, and their impact on the $\delta^{30} \mathrm{Si}$ compositions of exported dissolved and particulate phases. This will allow us to quantify the impact of Si exported from GrIS on the wider silica cycle and make predictions about how export from large ice sheets may change over longer timescales.

Here we combine new $\delta^{30}$ Si measurements of DSi and ASi phases with hydrogeochemical data from GrIS glacial catchments of contrasting scale over the summer melt season, in order to improve the current understanding of subglacial weathering processes.

\section{Methodology}

\subsection{Sampling locations}

We present hydrological and geochemical data from two polythermal- based, land terminating outlet glaciers from the GrIS, both of which have subglacial drainage systems that develop seasonally (Bartholomew et al., 2011). Data were collected from the proglacial river exiting Kiattuut Sermiat (KS; $61.2^{\circ} \mathrm{N}, 45.3^{\circ} \mathrm{W}$; Fig. 1) from April to August 2013 and Leverett Glacier, (LG; 67.06 ${ }^{\circ} \mathrm{N}$, $50.17^{\circ} \mathrm{W}$; Fig. 1) from May to July 2015 to capture the composition of meltwaters exiting the glaciers during the summer ablation season. KS is a small coastal glacier, covering an area of $36 \mathrm{~km}^{2}$ and currently terminating in a proglacial lake of approximately $0.5 \mathrm{~km}^{2}$ (Hawkings et al., 2016; Dubnick et al., 2017). Calculations using discharge records find the turnover time of the proglacial lake to be relatively short once the glacial melt season begins (less than 24 hours from Day 157, Supplementary Fig. 1), indicating that the lake will likely not have a significant effect on the meltwater chemistry downstream. In comparison, LG is a much larger glacier, with a hydrologically active catchment of around $600 \mathrm{~km}^{2}$ (Cowton et al., 2012), which feeds into Watson River and then into the Davis Strait via the Søndre Strømfjord (Hawkings et al., 2016). The composition of bedrock beneath LG is dominated by Precambrian Shield crystalline gneiss and granite, which is representative of the majority of GrIS (Escher, 1976) and much of the bedrock that was covered by the Eurasian and North American Ice Sheets (Bouysse, 2014). The bedrock at KS is relatively similar to LG, but there are some potential differences. KS overlays the Gardar Province, containing basalts, trachytes and phonolites. This region may also include syenites from the intrusive rocks of the Julianhåb batholith 
(Henriksen, 2009). However, previous work on $\delta^{30} \mathrm{Si}$ fractionation and elemental differentiation during high temperature processes in the mantle has shown limited isotope fractionation in comparison to weathering and biological processes (Savage et al., 2010).

We carried out hydrological monitoring of discharge, suspended sediment, $\mathrm{pH}$ and electrical conductivity using in-situ hydrochemical sensors (Fig. 1), as detailed by Kohler et al. (2017) and Hawkings et al. (2018). Water samples were collected at least once a day from just below the surface of the proglacial river using 1L Nalgene ${ }^{\mathrm{TM}}$ bottles (HDPE). Samples were filtered immediately using $0.45 \mu \mathrm{m}$ cellulose nitrate membrane filters (Whatman ${ }^{\circledR}$ ) mounted on a PS filtration stack (Nalgene ${ }^{\mathrm{TM}}$ ) and kept refrigerated in the dark until laboratory analysis. Samples for ASi concentrations and amorphous isotopic composition $\left(\delta^{30} \mathrm{ASi}\right)$ were collected by filtering approximately $500 \mathrm{ml}$ of the same water sample collected for dissolved analysis through a $0.45 \mu \mathrm{m}$ cellulose nitrate membrane filters (Whatman ${ }^{\circledR}$ ), retaining the sediment. Filters were kept refrigerated and in the dark until being gently air dried under a laminar flow hood prior to laboratory analysis.

\subsection{Major Ion Composition}

Water samples were analysed for major cation $\left(\mathrm{Na}^{+}, \mathrm{K}^{+}, \mathrm{Ca}^{2+}\right.$ and $\left.\mathrm{Mg}^{2+}\right)$ and anion $\left(\mathrm{NO}_{3}^{-}, \mathrm{SO}_{4}{ }^{2-}\right.$ and $\mathrm{Cl}^{-}$) concentrations by ion chromatography, with $\mathrm{HCO}_{3}{ }^{-}$estimated using the charge deficit (Tranter et al., 2002). Measurements were carried out using a Thermo Scientific ${ }^{\mathrm{TM}}$ Dionex $^{\mathrm{TM}}$ capillary ICS-5000 fitted with anion and cation columns (Hawkings et al., 2015; Dubnick et al., 2017).

\subsection{Silica concentrations}

DSi concentrations were determined spectrophotometrically using Flow Injection Analysis (FIA) on a LaChat 8500 series (QuikChem Method 31-114-27-1-D), as outlined by Hawkings et al. (2017). The limit of detection was $0.3 \mu \mathrm{M}$. Precision and accuracy $( \pm 0.54 \%$ and $\pm 1.9 \%)$ were determined by repeat measurements of a gravimetrically weighed $8.9 \mu \mathrm{M}$ standard $(\mathrm{n}=17)$. ASi was determined using an alkaline extraction method adapted from DeMaster (1981), as used by Hawkings et al. (2017). ASi was extracted from the suspended sediments collected on $0.45 \mu \mathrm{M}$ filters in the field. Briefly, $50 \mathrm{ml}$ $0.1 \mathrm{M} \mathrm{Na}_{2} \mathrm{CO}_{3}$ was added to $\sim 30 \mathrm{mg}$ (accurately weighed) of sediment at $85^{\circ} \mathrm{C}$ with $1 \mathrm{ml}$ aliquots taken at 2, 3 and 5 hours. Aliquots were neutralised immediately with $0.021 \mathrm{M} \mathrm{HCl}$ and stored at $4{ }^{\circ} \mathrm{C}$ until FIA analysis, using the same method as DSi concentrations. ASi (wt\%) was calculated following DeMaster (1981). $\mathrm{Na}_{2} \mathrm{CO}_{3}$ was preferred over $\mathrm{NaOH}$ extractions as it is the most commonly used alkaline extraction method of aquatic sediments, and is calibrated to clay minerals (Conley, 1998; Sauer et al., 2006; Hawkings et al., 2017). However, a $0.2 \mathrm{M} \mathrm{NaOH}$ extraction method was required to extract the total reactive silica for silicon isotope analysis and both methods have been compared to ensure consistency between the ASi concentrations reported and the ASi extracted for silicon isotope analysis. The $\mathrm{NaOH}$ extraction produced similar or slightly lower concentrations compared to the 
$\mathrm{Na}_{2} \mathrm{CO}_{3}$ method (Hawkings et al., 2018). Saturation indices for ASi were calculated for each timepoint using hydrochemical data from KS and LG and Debye-Hückel ion interaction model in Geochemists Workbench ${ }^{\circledR}$ Student Edition.

\subsection{Silicon Isotope Composition}

All silicon isotope analysis was completed in the Bristol Isotope Group laboratories (University of Bristol) using a Thermo Scientific ${ }^{\mathrm{TM}}$ Neptune Plus ${ }^{\mathrm{TM}}$ High Resolution MC-ICP-MS and a standardsample-standard bracketing procedure with $\mathrm{Mg}$ doping $(100 \mu 110 \mathrm{ppm} \mathrm{Mg})$ to correct for mass bias (Cardinal et al., 2003; Hendry and Robinson, 2012). International reference standard NBS-28 (NIST RM8546, purified quartz sand) was used as the bracketing standard and isotope compositions are reported in terms of $\delta^{30} \mathrm{Si}$ (Equation 1). Samples were doped with $50-100 \mu \mathrm{L} 0.1 \mathrm{M}$ sulphuric acid (Romil-UpA) to ensure matrix match between sample and standard, to reduce the mass bias effects of anion loading (Hughes et al., 2011). Instrument blanks were $<1 \%$ of ${ }^{28} \mathrm{Si}$ signal and typical internal reproducibility was $\pm 0.08 \%$ for $\delta^{30} \mathrm{Si}(2 \mathrm{SD})$ and $\pm 0.04 \%$ for $\delta^{29} \mathrm{Si}$ (2SD). Long term reproducibility of reference standards Diatomite and LMG08 (sponge) are reported as $+1.22 \pm 0.15 \%$ and -3.45 $\pm 0.14 \%$ o (2SD) respectively. Mass dependent fractionation is demonstrated by a three-isotope plot of all samples analysed during the study (Supplementary Fig. 2) with a gradient of 0.5118 (Reynolds et al., 2007).

Sediment samples for $\delta^{30} \mathrm{ASi}$ composition were prepared by adding $1 \mathrm{ml} 0.2 \mathrm{M} \mathrm{NaOH}$ per $0.1 \mathrm{mg} \mathrm{ASi}$ and heating at $100^{\circ} \mathrm{C}$ for 1 hour. Samples were diluted and acidified with $8 \mathrm{~N} \mathrm{HNO}_{3}$ and filtered through $0.22 \mu \mathrm{m}$ PES syringe filters. Bulk bedrock samples were processed using alkaline fusion (Georg et al., 2006) and the full procedure is detailed in Hawkings et al. (2018). Briefly, coarse, unsorted debris were crushed and ground to form a fine powder using a planetary ball mill (Fritsch Planetary Mono Mill Pulverisette 6). Debris was collected in front of the portal at LG and an ice cave into the front of KS. Samples were then furnaced at $730^{\circ} \mathrm{C}$ with a $\mathrm{NaOH}$ pellet (approximately $200 \mathrm{mg}$ ), diluted with MQ and acidified with $8 \mathrm{~N} \mathrm{HNO}_{3}$ once cool. Water samples were prepared for $\delta^{30} \mathrm{DSi}$ by preconcentrating the samples via evaporation to approximately $2 \mathrm{ml}$ sample, ensuring $2 \mathrm{ppm}$ of Si for analysis. All samples were then added to pre-cleaned BioRad exchange resin (AG50W-X12) columns and eluted with MQ water (Georg et al., 2006).

\section{Results}

\subsection{Defining periods of the melt seasons at KS and LG}

We categorise the melt season into three parts at KS, following Dubnick et al. (2017); Early Season, Transition Period and Late Season. These categories are defined by distinct changes in the proglacial river hydrochemistry. The Early Season is defined by low discharge and a lack of relationship 
between solutes, which is unlikely to reflect a subglacial signal. The Transition Period likely reflects the time when the subglacial system became hydrologically connected and the bulk meltwaters included a subglacially stored contribution (Hawkings et al., 2016; Dubnick et al., 2017). This period includes a "Spring Event", which is a time of high glacier velocity, associated with increases in subglacial water pressure discharge, suspended sediment and the divalent to monovalent cation ratio (Dubnick et al., 2017, Mair et al., 2004; Fig. 2). The Late Season had a bulk melt water signature that was distinct from the other periods analysed and is more similar to Alpine glacier geochemistry (Tranter et al., 2002, Tranter and Wadham., 2014).

We also categorise the melt season at LG into Early Season and Late Season, defined by differences in the hydrochemical data, with the transition being the first outburst event of the melt season. After this outburst event, the hydrochemistry of the meltwaters shifts towards those indicative of silicate mineral dissolution, as longer residence time waters are flushed.

\subsection{Dissolved major ions, DSi and $\delta^{30} \mathrm{DSi}$}

The ratio of $\left(\mathrm{Ca}^{2+}+\mathrm{Mg}^{2+}\right)$ to $\left(\mathrm{Na}^{+}+\mathrm{K}^{+}\right)$(divalent to monovalent cations, reported hereafter as $\left.\mathrm{D}: \mathrm{M}\right)$ has traditionally been used to indicate the amount of silicate weathering in relation to carbonate weathering (Tranter et al., 2002; Wadham et al., 2010). Elevated monovalent ion concentrations in relation to divalent concentrations are associated with enhanced silicate mineral weathering. The dissolved ion composition of glacial runoff from the two catchments changed significantly with seasonal evolution of the subglacial drainage system (Fig. 3). The discharge-weighted mean (Qwt) D:M ( $\mu$ eq $\mathrm{L}^{-1}: \mu \mathrm{eq} \mathrm{L}^{-1}$ ) at LG was 1.36 compared to 6.91 at KS, with the D:M decreasing at LG as the melt season progressed, from 5.18 to 1.44 , compared to an increase in the D:M of a smaller magnitude at $\mathrm{KS}$ (6.57 to 7.72, Fig. 3). $\mathrm{Ca}^{2+}$ was the dominant cation in $\mathrm{KS}$ over the entire melt season, consistent with previously documented meltwaters from Alpine and Polar glaciers. However, there was a shift from $\mathrm{Ca}^{2+}$ to $\mathrm{Na}^{+}$as the dominant cation as the melt season progressed at $\mathrm{LG}(\mathrm{Ca} / \mathrm{Na}$ molar ratios started at 3.23 and decreased to 0.56 during outburst events, Fig. 4).

DSi concentrations in LG meltwaters decreased as the season progressed due to dilution from supraglacial meltwaters $(56.9 \mu \mathrm{M}$ to $9.21 \mu \mathrm{M})$. The discharge weighted mean DSi concentration was $20.8 \mu \mathrm{M}$, similar to previously reported concentrations (Hindshaw et al., 2014; Hawkings et al., 2017). KS had a slightly higher discharge weighted mean DSi of $22.2 \mu \mathrm{M}$, with a range of $14.8 \mu \mathrm{M}$ to 41.8 $\mu \mathrm{M}$. Concentrations also decreased as the subglacial hydrological drainage system developed from inefficient to efficient drainage pathways (Supplementary Table 3 and 4).

There was a substantial decline in $\delta^{30} \mathrm{DSi}$ at LG as the melt season progressed and the subglacial system became hydrologically connected, with drainage of more isolated regions of the bed further up catchment (Fig. 5d). The discharge weighted mean value of $\delta^{30} \mathrm{DSi}$ at LG $(-0.25 \pm 0.12 \%$ ) was lighter than the previous riverine average $\delta^{30} \mathrm{DSi}$ composition ( $+1.25 \%$, Frings et al., 2016), and studies of 
glacially fed rivers in Iceland $(+0.17 \pm 0.18 \%$, Opfergelt et al., 2013). The lightest values measured at LG are more comparable to long residence time groundwaters (up to $-1.42 \%$, Georg et al., 2009). KS had a higher $\delta^{30} \mathrm{DSi}$, with a discharge weighted mean of $+0.41 \pm 0.10 \%$, although this value is also below the average riverine silicon isotope composition (Frings et al., 2016). The $\delta^{30} \mathrm{DSi}$ at KS also declined after the connection of the subglacial hydrological system ("Spring Event", Hawkings et al., 2016, Mair et al. 2004) but the decline was not as substantial as that seen at LG (Fig. 5c).

\subsection{Saturation Indices}

Bulk meltwaters in both catchments were highly undersaturated with respect to ASi throughout the melt season $\left(\mathrm{LG} \mathrm{SI}_{\mathrm{ASi}}=-1.04\right.$ to -1.85 and $\mathrm{KS} \mathrm{SI}_{\mathrm{ASi}}=-1.12$ to -1.73$)$. The lightest $\delta^{30} \mathrm{DSi}$ composition occurred when the proglacial river was most undersaturated with respect to ASi at both catchments (Supplementary Fig. 3).

\subsection{Bedrock, SPM, ASi concentration and $\delta^{30} \mathrm{ASi}$.}

Suspended particulate matter (SPM) concentrations in bulk meltwaters generally increased over time in both catchments, as increasing amounts of sediment were entrained subglacially (Fig. 2). LG ASi and SPM concentrations were significantly higher than KS (Table 1), with peak SPM coinciding with subglacial outburst events (Hawkings et al. 2016, Fig. 2). Particles at LG also had a higher relative proportion of extractable ASi, contributing to the elevated ASi concentrations ( $\mathrm{LG} \mathrm{Qwt} \mathrm{mean}=$ $0.73 \mathrm{wt} \%$, compared to KS Qwt mean $=0.23 \mathrm{wt} \%$ ). However, KS has a higher specific discharge than LG, so the yield of Si per $\mathrm{km}^{2}$ is higher at KS. We estimate a mean annual ASi yield of $1.75 \times 10^{4} \mathrm{~kg}$ $\mathrm{km}^{-2}$ from KS (Day 128 - 221) compared to an estimated mean yield of $1.24 \times 10^{4} \mathrm{~kg} \mathrm{~km}^{-2}$ from LG (Day $135-210)$.

The $\delta^{30} \mathrm{ASi}$ composition of SPM in bulk runoff was lighter at KS compared to LG, with little variation at either site over the monitoring period (discharge weighted mean of $-0.47 \pm 0.06 \%$ compared to $0.22 \pm 0.06 \%$, Fig. 5). These values were lower than the local bedrock (KS $-0.18 \pm 0.06 \%$, LG $0.00 \pm$ $0.07 \%$ ) and bulk suspended sediment (KS $-0.32 \pm 0.12 \%$, LG $-0.09 \pm 0.07 \%$ ).

\section{Discussion}

\subsection{Conceptual model of subglacial hydrology}

Differences in drainage system characteristics of glaciers at different spatial scale may result in contrasting chemical weathering environments and water export mechanisms (Wadham et al., 2010; Graly et al., 2014). Subglacial drainage systems of GrIS catchments likely include hydrological elements that exist for the majority of the year and those that develop over time and shut down during winter (Dubnick et al., 2017). The progression of the melt season is accompanied by an evolution from slow-inefficient distributed to efficient (and potentially channelised) drainage systems as more 
supraglacial meltwater reaches the bed (Bartholomew et al., 2011). Previous studies have demonstrated that the seasonal evolution of subglacial hydrology impacts nutrient export dynamics via the connection of chemically distinct, solute sources at the glacier bed (Bartholomew et al., 2011; Bhatia et al., 2013; Hawkings et al., 2016; Dubnick et al., 2017; Kohler et al., 2017). LG has a hydrologically active catchment of $\sim 600 \mathrm{~km}^{2}$, is $80 \mathrm{~km}$ long and has inland ice of low topography, favouring the formation of large supraglacial lakes (often $\sim$ kms in diameter, Hoffman et al., 2011). These supraglacial lakes can drain rapidly (<2hours) through moulins to the glacier bed as a result of hydrofracturing (Das et al., 2008; Bartholomew et al., 2011). Such drainage events can result in outburst events being recorded in the proglacial hydrochemical records (Bartholomew et al., 2011; Hawkings et al., 2015). Proglacial river discharge, suspended sediment and electrical conductivity rapidly rise (Bartholomew et al., 2011, Hawkings et al., 2016; Fig. 2), as subglacially stored waters and sediment become hydrologically connected and flushed downstream by incoming supraglacial water (Bartholomew et al., 2011; Cowton et al., 2012; Chandler et al., 2013). Subglacial hydrological evolution from inefficient to efficient drainage at the bed progresses from marginal to inland locations, with artificial tracer work showing efficient drainage existing up to $40 \mathrm{~km}$ from the margin by late July (Chandler et al., 2013). This evolution is further supported by the seasonal progression of the ${ }^{14} \mathrm{C}$ age of exported POC at LG (Kohler et al., 2017). The inland progression of the subglacial system could mean that increasingly isolated meltwaters drain from the bed, since the interval between basal flushing events via supraglacial lake drainage or moulins is longer in more inland locations (potentially 10 months) compared to marginal locations (Harper and Humphrey, 1995). Residence time differences between marginal and the most isolated inland waters are therefore likely to exist, especially if similar regions of the bed are flushed annually (Fig. 6), with implications for weathering and redissolution processes.

$\mathrm{KS}$ is only $\sim 16 \mathrm{~km}$ in length and there is comparatively little altitudinal difference from snout to the top of the ablation area. Supraglacial lakes do not form at KS, thus some more isolated parts of the bed may not be annually flushed by surface-to-bed water flow. The subglacial drainage system development at KS is driven entirely by the progression of the snowline and the consequent opening of new moulins and crevasses for surface to bed water flow, similar to smaller Arctic and Alpine glaciers. Thus, the subglacial drainage system develops from inefficient distributed drainage, where water follows a tortuous flow path, to an efficient, channelised system as the ablation season progresses and meltwater inputs increase (Fig. 6, Tranter et al., 2002, Nienow et al., 2014). The absence of supraglacial lake drainage and the smaller catchment size will shorten average residence times of water emerging as bulk runoff. Any seasonal variation in subglacial water residence times is likely on the order of weeks rather than months. We propose that the full length of KS could be compared with the evolution of the first 10-20km of subglacial hydrology at LG prior to the onset of outburst events, as demonstrated by the relationship between discharge and $\delta^{30} \mathrm{DSi}$ (Fig. 5b). As there 
is a limited input of long residence time stored water with differing geochemical composition at $\mathrm{KS}$,

332 the chemical composition of the proglacial stream reflects a carbonate dominated weathering regime

333 (Tranter et al., 2002).

\section{$334 \quad 4.2$ Differences in weathering regimes}

335 Glacier size is hypothesised to have a major impact on chemical weathering via its influence upon

336 hydrological flow path length, and hence water residence times (Wadham et al., 2010). Our data show

337 clear differences in the major ion composition of bulk meltwaters draining from the study glacial

338 catchments (Figs. 3 and 7), indicating contrasting subglacial chemical weathering regimes. In larger

339 catchments silicate mineral dissolution is enhanced, as subglacially stored meltwaters reach saturation

340 with respect to calcite, due to the long residence times and subglacial isolation (Wadham et al., 2010;

341 Hawkings et al., 2016). Carbonate hydrolysis was previously believed to dominate over carbonation

342 in subglacial environments, due to the limited atmospheric connectivity, resulting in enhanced

343 concentration of divalent ions in meltwaters $\left(\mathrm{Ca}^{2+}+\mathrm{Mg}^{2+}\right.$; Equation 2, Tranter et al., 2002). By

344 comparison, silicate hydrolysis results in elevated concentrations of monovalent ions $\left(\mathrm{Ka}^{+}+\mathrm{Na}^{+}\right.$;

345 Equation 3, Tranter and Wadham, 2014).

\section{$346 \quad$ Leverett Glacier}

347 At LG, the progressive evolution in the D:M ratio is consistent with a shift towards silicate dominated 348 mineral weathering as the melt season progresses (Fig. 3). This trend in D:M is also consistent with

349 the Na-normalised molar ratios, which can be used to compare the hydrochemical signature to silicate

350 and carbonate endmembers in mixing diagrams (Gaillardet et al., 1999). Fig. 4 shows the evolution of

351 the LG towards the silicate endmember as the melt season progresses, with the outburst events lying

352 closest to this endmember. This suggests that isolated meltwaters characterised by long residence

353 times become hydrologically connected to a fast, efficient drainage systems and are exported to the

354 ice margin.

355 Subglacial meltwaters in inland regions may only be flushed by surface melt (e.g. via lake drainage

356 and moulins) after $\sim 10$ months when the snowline retreats this far from the ice margin and inland

357 hydrological systems become connected. During the intervening period, these subglacial meltwaters

358 are inferred to undergo enhanced silicate dissolution (Wadham et al., 2010; Chandler et al., 2013;

359 Graly et al., 2014). Hydrolysis of silicates also increases the $\mathrm{pH}$ within subglacial waters (Equations 2

360 and 3, Fig. 2), and these higher $\mathrm{pH}$ conditions further enhance the dissolution of aluminosilicate

361 minerals (Georg et al., 2009; Tranter and Wadham, 2014). Evolution towards low D:M ratios, and

362 elevated $\mathrm{pH}$ is particularly pronounced from Day 170 onwards in 2015 at LG after the first subglacial

363 outburst event ( $\mathrm{Q}_{\mathrm{wt}} \mathrm{pH}$ after first outburst event 8.71, Fig. 2). 
Coupled carbonate dissolution and sulphide oxidation is a more important process, during the Early Season at LG. This importance is illustrated by gradients of $\mathrm{Ca}^{2+}+\mathrm{Mg}^{2+}$ versus $\mathrm{SO}_{4}{ }^{2-}$ (Fig. 7a) and of $\mathrm{Ca}^{2+}+\mathrm{Mg}^{2+}$ versus $\mathrm{HCO}_{3}{ }^{-}$(Fig. 7b) close to 2 (1.93 and 1.50 respectively, Tranter et al., 2002), which closely resemble molar equivalent ratios of $2: 1$ for $\mathrm{Ca}^{2+}+\mathrm{Mg}^{2+}$ and $\mathrm{SO}_{4}{ }^{2-}$, and $\mathrm{Ca}^{2+}+\mathrm{Mg}^{2+}$ and $\mathrm{HCO}_{3}$, according to Equation 5. These findings are similar to those found by Graly et al. (2017), but are not seen in a study which focused upon the middle to late part of the melt season at LG (Hindshaw et al., 2014). We find higher concentrations of $\mathrm{SO}_{4}{ }^{2-}$ in 2015 during the Early Season when discharge was lower (Supplementary Fig. 4), which we can attribute to sulphide oxidation, highlighting the importance of categorising the development of the melt season due to potentially large seasonal differences. Furthermore, during the Early Season, the sulphate mass fraction (SMF, Equation 6) is higher than later in the season (Supplementary Fig. 5), indicating a larger proportion of protons result from sulphide oxidation. However, a SMF of $<0.5$ throughout the melt season indicates carbonation is overall more important that sulphide oxidation as a proton supplier.

Following the first outburst event (Late Season), the gradients of $\mathrm{Ca}^{2+}+\mathrm{Mg}^{2+} \mathrm{v} \mathrm{SO}_{4}{ }^{2-}$ and $\mathrm{Ca}^{2+}+\mathrm{Mg}^{2+}$ v $\mathrm{HCO}_{3}{ }^{-}$became shallower $\left(\mathrm{Ca}^{2+}+\mathrm{Mg}^{2+}: \mathrm{SO}_{4}{ }^{2-}=1.50: 1, \mathrm{Ca}^{2+}+\mathrm{Mg}^{2+}: \mathrm{HCO}_{3}{ }^{-}=0.79: 1\right)$. The SMF also decreases $(\sim 0.45$ to $\sim 0.25)$, indicating protons are largely provided from carbonation reactions. It is likely that silicate dissolution via hydrolysis and carbonation is occurring in the Late Season at LG (Wadham et al., 2010), especially when considering the concomitant increase in the gradient of the lines of best fit for associations between $\mathrm{HCO}_{3}{ }^{-}$and $\mathrm{SO}_{4}{ }^{2-}$ (Fig. $7 \mathrm{c}$ and embedded Table) from Early to Late season at $\mathrm{LG}$ (0.96 to 1.17). Carbonation of silicates and carbonates consumes $\mathrm{CO}_{2}$ in solution and result in formation of $\mathrm{HCO}_{3}{ }^{-}$, which, combined with silicate hydrolysis, also helps to explain the increasing $\mathrm{pH}$ as the melt season progresses. We expect that this increase in $\mathrm{pH}$ is the result of increased hydrolysis and carbonation of silicates, due to the decline of $\mathrm{Ca}^{2+}+\mathrm{Mg}^{2+}: \mathrm{HCO}_{3}{ }^{-}$ratios as the season progresses, indicating that the addition of $\mathrm{HCO}_{3}{ }^{-}$is occurring in the absence of $\mathrm{Ca}^{2+}+\mathrm{Mg}^{2+}$.

The meltwater geochemistry therefore suggests that LG begins as a system with the imprint of sulphide oxidation coupled to carbonate dissolution ( $\mathrm{SMF}=\sim 0.45$, Equation 5 ). As the season progresses and more isolated waters are exported, there is an increased importance of silicate weathering linked to carbonation reactions $(\mathrm{SMF}=\sim 0.2)$.

\section{$\underline{\text { Kiattuut Sermiat }}$}

Our conceptual model of the hydrology at KS leads to predictions of a relatively consistent subglacial weathering regime once an efficient drainage system has developed. The source of solute in the meltwaters at KS appears fairly consistent over the melt season. D:M ratio and mixing diagrams at KS indicates that the system is dominated by carbonate weathering (Figs. 3, 4; also see Dubnick et al. 2017). We can use the ionic ratios to interrogate these relationships further and assess differences between Early Season, Transition Period and Late Season. 
During the Early Season at KS there is no significant relationships between $\mathrm{Ca}^{2+}+\mathrm{Mg}^{2+}$ and $\mathrm{HCO}_{3}^{-}$ versus $\mathrm{SO}_{4}{ }^{2-}$. We would expect the higher $\mathrm{SO}_{4}{ }^{2-}$ concentrations to be a result of sulphide oxidation. Sulphide oxidation would usually be coupled with carbonate dissolution in glacial systems, which should be reflected in molar equivalent ratios (Equation 5). However, the discharge is low at this time, so it is likely that the proglacial river reflects groundwaters diluted with some snowmelt and/or precipitation. Groundwater flow may be torturous, impacting upon the ionic ratios, and it is also likely that these waters are more affected by atmospheric deposition than later in the season when discharge is much greater (Bhatia et al., 2013). In the Early Season there are also longer turnover times of lake water due to the lower discharge entering the lake, which results in slower flushing of system (Supplementary Fig. 1).

It is during the Transition Period that the gradients for all the major ion relationships most closely match those during the Early Season at LG (Fig. 7). There was an increase of $\mathrm{HCO}_{3}{ }^{-}$and $\mathrm{Ca}^{2+}+\mathrm{Mg}^{2+}$ in relation to $\mathrm{SO}_{4}{ }^{2-}$ (Fig. 7a and 7c), which could be evidence of the connection of the subglacial system to the proglacial hydrological system. As the dissolution of freshly comminuted glacial sediments preferentially release $\mathrm{HCO}_{3}{ }^{-}$and $\left(\mathrm{Ca}^{2+}+\mathrm{Mg}^{2+}\right)$ (via hydrolysis of trace carbonates), it would be expected that the $\mathrm{HCO}_{3}{ }^{-}$and $\mathrm{Ca}^{2+}+\mathrm{Mg}^{2+}$ ratios with respect to $\mathrm{SO}_{4}{ }^{2-}$ would increase. The elevated $\mathrm{HCO}_{3}{ }^{-}$could also result from the microbial oxidation of organic carbon (Wadham et al., 2010). The higher intercepts of $\mathrm{HCO}_{3}{ }^{-} \mathrm{v} \mathrm{SO}_{4}{ }^{2-}$, and $\left(\mathrm{Ca}^{2+}+\mathrm{Mg}^{2+}\right) \mathrm{V} \mathrm{SO}_{4}{ }^{2-}$ compared to $\mathrm{LG}$, suggest rapid acquisition of $\left(\mathrm{Ca}^{2+}, \mathrm{Mg}^{2+}\right)$ and $\mathrm{HCO}_{3}{ }^{-}$in relation to $\mathrm{SO}_{4}{ }^{2-}$, potentially due to carbonate hydrolysis. Also, during the Transition Period, the $\left(\mathrm{Ca}^{2+}+\mathrm{Mg}^{2+}\right)$ : $\mathrm{HCO}_{3}$ ratio increased to 1.50 (Fig. 7b), and the SMF increased to $\sim 0.18$ (Supplementary Fig. 5). Collectively, these observations indicate some influence from carbonate dissolution coupled to sulphide oxidation (Equation 5), similar to the Early Season meltwaters at LG.

We see a prevalence of carbonate over silicate weathering during the Late Season at KS, providing evidence of continuous availability of carbonate minerals within the subglacial system and a lack of calcite saturation. Relationships close to $1: 1$ for $\left(\mathrm{Ca}^{2+}+\mathrm{Mg}^{2+}\right)$ : $\mathrm{HCO}_{3}$ (Fig. 7b) show that carbonation of carbonates and carbonate hydrolysis are the dominate weathering reactions throughout the melt season, as a 1:1 ratio is expected from Equation 2.

The values measured at KS are similar to bulk meltwaters of Alpine glaciers studied, although the $\mathrm{SO}_{4}{ }_{4}^{2-}$ concentrations in the outflow from KS are lower (Tranter et al., 2002). The overall major ion relationships indicate a shift from carbonate hydrolysis (Equation 2) and coupled carbonate dissolution-sulphide oxidation (Equation 5) to carbonation of carbonates as the melt season progresses, with little evidence of enhanced silicate weathering.

\subsection{Catchment hydrology as a driver of $\delta^{30} \mathrm{DSi}$ seasonal variability}


By combining our conceptual model of subglacial hydrology at LG and KS with the observed major ion ratio chemistry, we can begin to understand the geochemical drivers behind variations in $\delta^{30} \mathrm{Si}$ composition of the meltwaters in each catchment. An increased predominance of silicate dissolution as the melt season progresses at LG should theoretically result in higher $\delta^{30} \mathrm{DSi}$, as silicate weathering and the formation of secondary weathering products preferentially incorporate the lighter isotopes into the newly formed solid (De La Rocha et al., 2000; Frings et al., 2016). While this pattern is observed in non-glacial regimes, the lowest $\delta^{30} \mathrm{DSi}$ values measured at LG coincided with the most pronounced silicate weathering signals, and likely, by association, the longest residence time waters. We hypothesise that the low $\delta^{30} \mathrm{DSi}$ values measured at LG after Day 170 reflect the dissolution of isotopically light ASi and secondary weathering products in subglacially stored waters and/or the dissolution of isotopically light fresh mineral surface layers formed by enhanced physical weathering (Hawkings et al., 2018). As the melt season progressed, the hydrologically active part of the catchment retreated further inland and more isolated subglacial waters became hydrologically connected (Hawkings et al., 2015), resulting in decreasing $\delta^{30}$ DSi (Fig. 5b) and D:M ratios as discharge rose (Fig. 5a). The declining D:M ratios indicate a move to increasingly dominant silicate weathering and redissolution of secondary weathering products from the more isolated subglacial system or longer residence time waters, resulting in more dissolution of these finely ground weathering crusts, which results in the lowering of the $\delta^{30} \mathrm{DSi}$ composition.

Some decline in $\delta^{30} \mathrm{DSi}$ also occurred during the Transition Period at KS (Fig. 5c), which was likely linked to the opening of subglacial hydrological pathways and flushing of a formerly distributed drainage system. We would expect redissolution of secondary weathering products to occur at KS due to the high $\mathrm{pH}$ and the undersaturation of ASi (Crompton et al., 2015, Supplementary Fig. 3). However, $\delta^{30} \mathrm{DSi}$ composition at KS is consistently higher than $\delta^{30} \mathrm{ASi}$ and bedrock values (Fig. $4 \mathrm{~d}$ ), indicating that the $\delta^{30} \mathrm{DSi}$ exported is a result of fractionation due to net secondary weathering product formation (Crompton et al., 2015). We hypothesis that the shorter residence times beneath KS compared to LG reduce the potential for redissolution of secondary weathering products to occur. It is more likely that there are fewer inland regions that remain isolated at KS, and the supraglacial waters are routed more efficiently through the subglacial system.

KS and LG have broadly similar bedrock compositions (Hawkings et al., 2016), with any differences unlikely to have a major impact on the overall $\delta^{30} \mathrm{Si}$ composition of the measured bulk bedrock

\section{3 (Savage et al., 2010). The intrusive rocks of the Julianhåb batholith and the Gardar Province at KS} would be expected to have a limited range in $\delta^{30} \mathrm{Si}$ values due to minimal isotope fractionation during high temperature mantle processes (Savage et al., 2010; Savage et al., 2014). Therefore, our measurements of crushed proglacial rock debris for both catchments are in good agreement with the published range of values measured in West Greenland (Andre et al., 2006). The measured mean bedrock values of $\delta^{30} \mathrm{Si}$ at KS are lighter compared to LG (-0.18 $\pm 0.06 \%$ compared to $0.00 \pm 0.07 \%$ ), 
making them more comparable to values for bulk silicates on the Earth's surface $(-0.29 \pm 0.08 \%$, Savage et al. 2010). The heavier $\delta^{30} \mathrm{Si}$ composition measured at LG could be an artefact of sampling bedrock with a weathering crust, rather than pristine samples. However, basalts have a lower isotopic composition (-0.3\%o to $-0.2 \%$, Georg et al., 2007; Chemtob et al., 2015), so it is possible KS bedrock is isotopically lighter, as a result of basaltic intrusions. Nevertheless, we attribute variations in silicon isotope composition of SPM ASi to be largely a result of weathering processes at the glacier bed. The isotopic fractionations caused by weathering conditions has been shown to be much greater than any variations in crustal samples, despite often significant differences in compositions (Ziegler et al., 2005; Savage et al., 2010; Savage et al., 2013).

Neither catchment showed a seasonal trend in SPM $\delta^{30} \mathrm{ASi}$, which exhibited a constant offset towards lower values compared to our bulk bedrock measurements ( 0.1 to $0.2 \%$; Fig. $5 \mathrm{c}$, d). The offset could be the result of fractionation induced precipitation reactions, weathering of silicate rocks, comminution of particles, or a combination of all three (Andre et al., 2006; Chemtob et al., 2015). The precipitation of $\mathrm{ASi}$ at low temperatures results in the preferential uptake of ${ }^{28} \mathrm{Si}$ into the solid phase (e.g. Geiler et al. 2014). High resolution transmission electron microscope photomicrographs of ASi in SPM show it to be associated with edges of particles and with elements such as $\mathrm{Al}$ and $\mathrm{Fe}$, suggesting it potentially forms as a result of aluminosilicate mineral weathering (Hellmann et al., 2012; Hawkings et al., 2017). The presence of ASi with elevated Al/Si ratios indicates that it would also be enriched in ${ }^{28} \mathrm{Si}$, based on prior low temperature laboratory experiments (Oelze et al., 2015). However, the offset in SPM $\delta^{30} \mathrm{ASi}$ from the bedrock measurements could also be linked to physical grinding, which has been demonstrated to result in the formation of reactive amorphous surface layers (Lin and Somasundaran, 1972; Hawkings et al., 2017). ASi formed in this way is likely to be characterised by isotopically light compositions as it is derived from the alteration of a freshly crushed outer mineral layer, enriched in ${ }^{28} \mathrm{Si}$, due to kinetic fractionation (Zielger et al., 2005). All three processes result in ASi enriched in ${ }^{28} \mathrm{Si}$, so our current data is unable to infer which of these is most important as ASi from both catchments are lighter than bedrock values across the season.

\subsection{Understanding the Isotopic Mass Imbalance}

The interpretations presented above highlight a potential mass imbalance that arises because the subglacial waters export both DSi and ASi that is isotopically lighter than bedrock values at LG. In addition to this, when the $\delta^{30} \mathrm{DSi}$ and $\delta^{30} \mathrm{ASi}$ compositions at LG are summed, considering the relative contributions of both, the total $\delta^{30} \mathrm{Si}$ is consistently lighter than the measured bedrock across the melt season. Whilst we have sampled the majority of the melt season at LG (>60\%), we did not continue sampling until the shutdown of the subglacial system. Therefore, we have carried out a simple mass balance calculation to ensure the mass imbalance seen at LG is not simply an artefact of the unmonitored part of the season (Supplementary Table 5). Whilst we do not have geochemical data 
past Day 210, we have a continuous discharge (Q) record until much later in the season. From this record we calculated the proportion of the measured discharge compared to the total discharge. We assumed that DSi concentrations were similar to the discharge weighted mean from the measured period. As the $\delta^{30} \mathrm{ASi}$ composition was relatively constant across the measured period, this trend would likely continue into the latter stages of the season. We estimate the $\delta^{30} \mathrm{Si}$ composition of the unmeasured DSi required to ensure the total Si exported had a $\delta^{30} \mathrm{Si}$ composition that matched the bulk bedrock composition. The overall $\delta^{30} \mathrm{Si}$ composition after the sampling period would need to be $+0.44 \%$, with a $\delta^{30} \mathrm{DSi}$ composition of $+2.22 \%$, in order to balance the $\delta^{30} \mathrm{Si}$ composition over the rest of the melt season. The aim of this simple calculation was to demonstrate whether the mass imbalance could be realistically resolved by only considering the latter stages of the melt season, which we were unable to sample. A $\delta^{30} \mathrm{DSi}$ composition of $+2.22 \%$ is likely unrealistic, considering the range of values measured over the rest of the season are significantly lighter. It is therefore likely the subglacial processes are driving the mass imbalance seen at LG.

One hypothesis to explain this mass imbalance is that the continuing light $\delta^{30} \mathrm{DSi}$ values of bulk meltwaters reflect physical erosion processes. High physical erosion of bedrock under the GrIS results in the formation of fresh finely ground rock flour, with very high surface areas (Cowton et al., 2012; Telling et al., 2015; Hawkings et al., 2016; Nienow et al., 2017). Published dissolution experiments have shown there is a preferential dissolution of ${ }^{28} \mathrm{Si}$ from the fresh mineral surface, as a result of kinetic fractionation (Ziegler et al., 2005). Therefore, we expect that the freshly crushed subglacial minerals to result in delivery of dissolved silicon enriched in ${ }^{28} \mathrm{Si}$. The high $\mathrm{pH}$ and under saturation of waters with respect to ASi subsequently promotes the outer amorphous mineral layers to undergo further dissolution, resulting in the export of light $\delta^{30} \mathrm{DSi}$. The higher $\delta^{30} \mathrm{DSi}$ composition at the beginning of the season reflects the weathering environment at marginal areas of the ice sheet. These areas are accessed more regularly by surface melt, with efficient hydrological drainage for longer parts of the season (Chandler et al., 2013), and with potentially less active grinding of bedrock (as demonstrated by lower suspended sediment concentrations during the Early Season). As the melt season progresses, more isolated inland regions of the bed are accessed, where dissolution has occurred over longer time periods and where physical erosion is enhanced, potentially evidenced by the linear relationship between increasing SPM concentrations and decreasing $\delta^{30} \mathrm{DSi}$ exported from LG (Supplementary Fig. 6). Hence, the $\delta^{30} \mathrm{DSi}$ of meltwaters exported is lower. By comparison, SPM concentrations exported from KS are consistently lower. This could be a result of some settling in the proglacial lake, but we believe it is more likely to result from lower rates of physical erosion in this smaller catchment. We therefore hypothesise that higher physical erosion rates and longer residence times in larger catchments (Wadham et al., 2010, Hawkings et al., 2016), help to explain the differences in the $\delta^{30} \mathrm{Si}$ composition of meltwaters from LG and KS. 
To quantitatively assess if this hypothesis is realistic, we have modelled the proportion of DSi that would need to result from the dissolution of ASi associated with SPM, assuming complete dissolution, when considering the $\delta^{30} \mathrm{Si}$ composition of the measured DSi and corresponding endmembers (Equation 7). Our model was based on a range of fractionation factors for the initial formation of $\mathrm{ASi}(\varepsilon)$ from the alteration of bedrock, as low temperature fractionation processes are still poorly understood (Geilert et al., 2014; Frings et al., 2016). An open system was chosen, rather than using Rayleigh fractionation, as we do not expect a finite pool of Si within the subglacial system in the timescales we are considering.

The subglacial environment is complex; therefore, so we have simplified our model by assuming overall fractionation during bedrock alteration to form ASi is similar to that observed during low temperature ASi precipitation from solution with $\varepsilon$ ranging from $-2 \%$ to $-5 \%$. Extrapolation from experiments by Geilert et al. (2014) produces a fractionation factor of $-2.34 \%$ at $0^{\circ} \mathrm{C}$. However their conclusions indicate that the fractionation factor at low temperatures is system dependent, due to differences in fractionation based on external factors such as saturation state and surface area. Oelze et al. (2015) found a fractionation factor of $-5 \%$ o for initial stages of experiments with high $\mathrm{Al} / \mathrm{Si}$ ratios, which could simulate subglacial conditions considering the potential formation of ASi through aluminosilicate weathering (Hawkings et al., 2017). We use the first $\delta^{30} \mathrm{DSi}$ value measured in the Early Season at KS and a value measured at the subglacial portal in the Early Season at LG as the initial $\delta^{30} \mathrm{DSi}$ endmember in the model. The $\delta^{30} \mathrm{ASi}$ endmember value is calculated by subtracting the chosen fractionation factor from the $\delta^{30} \mathrm{Si}$ composition of the bulk rock for each catchment.

In our modelled scenarios for LG we show that during outburst periods (and thus when $\delta^{30} \mathrm{DSi}$ composition is lightest), a maximum of $56 \%$ of the measured DSi results from ASi dissolution (Fig. 8). This proportion equates to $\sim 12 \mu \mathrm{M}$ of ASi compared to an overall ASi concentration of $\sim 290 \mu \mathrm{M}$ measured at the same timepoint, suggesting that even the maximum modelled values can be considered reasonable due to the large ASi reservoir. Experimental data also suggest the most negative $\varepsilon$ values relate to solids formed rapidly and with unidirectional kinetic fractionation effects (Oelze et al., 2015), which could also relate to these subglacial weathering crusts which are highly reactive and would presumably undergo rapid dissolution. While all the modelled $f_{a}$ values can be considered realistic when converted to molar concentrations, we consider the lower values as more representative of subglacial systems, considering the experimental data from Oelze et al. (2015).

Despite the lower ASi concentrations at KS, the modelled values can also be considered realistic for this system. As we expect the ASi dissolution to be less important at KS compared to at LG, it follows that we calculate lower proportions of ASi required to undergo dissolution in order to produce the measured $\delta^{30} \mathrm{DSi}$. We would expect the DSi at KS to be a result of silicate dissolution, from 
hydrolysis reactions, with the formation of clay minerals as a secondary weathering product

577 (Crompton, 2015), as evidenced by increasing $\mathrm{pH}$ and the heavier $\delta^{30} \mathrm{DSi}$ when compared to LG.

578 An alternative hypothesis to explain the mass imbalance at LG requires a temporal offset between 579 weathering product formation and re-dissolution. For example, the isotopically light secondary

580 weathering products may be a pre-glacial feature formed in a past, warmer climatic regime,

581 sequestered by an advancing ice sheet under a cooler climate and were stored subglacially (Hawkings

582 et al., 2018). The presence of palaeosols (>2.7million years, Bierman et al. 2014 ) beneath the ice

583 sheet, which are exported in runoff, supports the notion that there are pre-glacial features present

584 (Lawson et al., 2014; Kohler et al., 2017). The high pH of LG meltwaters (up to 9.63),

585 undersaturation of waters with respect to ASi, and high ASi concentrations (Qwt mean $209 \mu \mathrm{M}$ after

586 Day 170), could result in the redissolution of these isotopically light amorphous secondary weathering

587 products when the isolated parts of the subglacial system become hydrologically connected

588 (Hawkings et al., 2018). Whilst this hypothesis provides explanation for the potential mass imbalance

589 and palaeosols are evidenced beneath ice sheets, it may be expected that this isotopically light source

590 of Si would get depleted over time and any enhanced weathering currently occurring in-situ would

591 result in heavier $\delta^{30} \mathrm{DSi}$ exported in the meltwaters. Also, ASi measurements in the current proglacial

592 plain display very low concentrations (average $0.01 \mathrm{wt} \%$, Supplementary Table 6), suggesting these

593 amorphous phases are not currently being formed in the current proglacial environment, or have been

594 stripped away or aged. Therefore, whilst this hypothesis has potential to provide explanation for light

$595 \delta^{30} \mathrm{DSi}$ compositions in glacial meltwaters, our data suggests our first hypothesis focusing on physical 596 erosion is currently the most likely scenario.

\section{$597 \quad 4.5$ Implications and Conclusions}

598 The two Greenland Ice Sheet (GrIS) catchments have different subglacial weathering regimes

599 primarily driven by subglacial hydrology. These weathering regimes appear related to water residence

600 time and therefore catchment size. Kiattuut Sermiat (KS) was dominated by carbonate hydrolysis,

601 whereas a predominance of silicate mineral weathering occurred as the melt season progressed at

602 Leverett Glacier (LG). Subglacial silicate weathering results in the production of isotopically light

603 amorphous secondary weathering solid phases in both catchments, with heavier isotopes recorded in

604 the dissolved fraction during Early Season meltwater discharge. As the melt season progressed, long

605 residence time subglacial waters became connected to an efficient drainage system. The larger of the

606 two catchments in this study, LG, exhibited a marked decrease in $\delta^{30} \mathrm{DSi}$ from 0.87 to $-0.55 \%$, as

607 meltwater discharge rose, and the subglacial drainage system expanded inland, tapping increasingly

608 remote subglacial water pockets. We interpret this isotopic shift as evidence of increasing contribution

609 from silicate weathering products, including the dissolution of ASi and other secondary weathering

610 products, and leaching of freshly crushed rock surfaces. The smaller catchment, KS, discharged 
meltwaters with a $\delta^{30} \mathrm{DSi}$ similar to smaller valley glaciers, with carbonate weathering the predominant solute acquisition pathway.

Our results show that $\delta^{30} \mathrm{DSi}$ and $\delta^{30} \mathrm{ASi}$ can be used alongside major ion data to assess the degree of silicate weathering, redissolution of weathering products and hydrological drainage characteristics in glacial meltwaters. We postulate that access to meltwater present in subglacial drainage systems with limited connection to an efficient drainage system will increase in the future, as snowlines retreat further inland and melt increases under climatic warming (Hawkings et al., 2015). It is therefore likely that the intensity of subglacial geochemical weathering and the composition of glacial waters entering the ocean will be impacted. These findings are critical when attempting to estimate the fluxes of nutrients from rapidly melting glaciated regions and their impact on elemental cycles, in the past (e.g. during deglaciation events, Hawkings et al., 2018), present and future. The residence time of subglacial waters will have an influence on the weathering reactions occurring, and therefore the fluxes of key nutrients (Fe, P and Si) exported from glacial systems (Stevenson et al., 2017). More robust estimation of Si fluxes and the $\delta^{30} \mathrm{Si}$ composition of exported waters from the GrIS requires full consideration and further study of catchment size, hydrological development, weathering regime, and other processes within the complex subglacial system. The degree of silicate weathering in glaciated regions may be much higher than previously thought, considering that it is the larger catchments that discharge the majority of meltwater into the ocean from the GrIS and AIS. The quantity of meltwater delivered Si from ice sheets and its isotopic composition should therefore be considered when calculating global silicon budgets.

\section{Acknowledgements}

This research is part of ERC funded project ICY-LAB (ERC-StG-ICY-LAB-678371), NERC funded project DELVE (NERC grant NE/I008845/1) and a Leverhulme Trust Research Grant (RPG-2016-439). JRH was additionally supported by the European Union's Horizon 2020 research and innovation programme under the Marie Sklodowska-Curie Actions fellowship ICICLES (grant agreement \#793962). Fieldwork was additionally supported by a Czech Science Foundation Junior Grant (GACR 15-17346Y). TJK further supported by Charles University Research Centre program No. 204069. Authors thank all those involved in fieldwork at Leverett Camp and Kiattuut Sermiat Camps over both field seasons. We also thank the technical support from Bristol Isotope Group (Dr. C. D. Coath, L. Cassarino and Dr. H. C. Ng) and LOWTEX laboratories at the University of Bristol (J. Williams and Dr. F. Sgouridis). The authors also thank the reviewers and associate editor for their comments to improve the manuscript. 
Andre L., Cardinal D., Alleman L. and Moorbath S. (2006) Silicon isotopes in 3.8 Ga West Greenland rocks as clues to the Eoarchaean supracrustal Si cycle. Earth and Planetary Science Letters 245, 162173.

Bartholomew I., Nienow P., Sole A., Mair D., Cowton T., Palmer S. and Wadham J. (2011) Supraglacial forcing of subglacial drainage in the ablation zone of the Greenland ice sheet. Geophysical Research Letters 38.

Berner R.A. (2003) The long-term carbon cycle, fossil fuels and atmospheric composition. Nature 426, 323.

Bhatia M.P., Das S.B., Xu L., Charette M.A., Wadham J.L. and Kujawinski E.B. (2013) Organic carbon export from the Greenland ice sheet. Geochim. Cosmochim. Acta 109, 329-344.

Bierman P.R., Corbett L.B., Graly J.A., Neumann T.A., Lini A., Crosby B.T. and Rood D.H. (2014)

Preservation of a Preglacial Landscape Under the Center of the Greenland Ice Sheet. Science 344, 402-405.

Bouysse P. (2014) Geological Map of the World at 1: 35000 000, 3rd Edition ed. CCGM-CGMW. Cardinal D., Alleman L.Y., de Jong J., Ziegler K. and Andre L. (2003) Isotopic composition of silicon measured by multicollector plasma source mass spectrometry in dry plasma mode. Journal of Analytical Atomic Spectrometry 18, 213-218.

Cardinal D., Gaillardet J., Hughes H.J., Opfergelt S. and André L. (2010) Contrasting silicon isotope signatures in rivers from the Congo Basin and the specific behaviour of organic-rich waters. Geophysical Research Letters 37.

Chandler D.M., Wadham J.L., Lis G.P., Cowton T., Sole A., Bartholomew I., Telling J., Nienow P., Bagshaw E.B., Mair D., Vinen S. and Hubbard A. (2013) Evolution of the subglacial drainage system beneath the Greenland Ice Sheet revealed by tracers. Nature Geosci 6, 195-198.

Chemtob S.M., Rossman G.R., Young E.D., Ziegler K., Moynier F., Eiler J.M. and Hurowitz J.A. (2015) Silicon isotope systematics of acidic weathering of fresh basalts, Kilauea Volcano, Hawai'i. Geochim. Cosmochim. Acta 169, 63-81.

Conley D.J. (1998) An interlaboratory comparison for the measurement of biogenic silica in sediments. Marine Chemistry 63, 39-48.

Cowton T., Nienow P., Bartholomew I., Sole A. and Mair D. (2012) Rapid erosion beneath the Greenland ice sheet. Geology 40, 343-346.

Crompton J.W., Flower, G. E., Kirste, D., Hagedorn, B., and Sharp, M. J. (2015) Clay mineral precipitation and low silica in glacier meltwaters explored through reaction-path modelling. Journal of Glaciology 61, 1061-1078.

Das S.B., Joughin I., Behn M.D., Howat I.M., King M.A., Lizarralde D. and Bhatia M.P. (2008) Fracture Propagation to the Base of the Greenland Ice Sheet During Supraglacial Lake Drainage. Science 320, 778-781.

De La Rocha C.L., Brzezinski M., A. and DeNiro M.J. (2000) A first look at the distribution of the stable isotopes of silicon in natural waters. Geochim. Cosmochim. Acta 64, 2467-2477.

De la Rocha C.L., Brzezinski M.A. and DeNiro M.J. (1997) Fractionation of silicon isotopes by marine diatoms during biogenic silica formation. Geochim. Cosmochim. Acta 61, 5051-5056.

DeMaster D., J. (1981) The Supply and Accumulation of Silica in the Marine-Environment. Geochim. Cosmochim. Acta 45, 1715-1732.

Ding T., Wan D., Bai R., Zhang Z., Shen Y. and Meng R. (2005) Silicon isotope abundance ratios and atomic weights of NBS-28 and other reference materials. Geochim. Cosmochim. Acta 69, 5487-5494. Ding T., Wan D., Wang C. and Zhang F. (2004) Silicon isotope compositions of dissolved silicon and suspended matter in the Yangtze River, China. Geochim. Cosmochim. Acta 68, 205-216. Ding T.P., Gao J.F., Tian S.H., Wang H.B. and Li M. (2011) Silicon isotopic composition of dissolved silicon and suspended particulate matter in the Yellow River, China, with implications for the global silicon cycle. Geochim. Cosmochim. Acta 75, 6672-6689. 
Dubnick A., Kazemi S., Sharp M., Wadham J., Hawkings J., Beaton A. and Lanoil B. (2017) Hydrological controls on glacially exported microbial assemblages. Journal of Geophysical Research: Biogeosciences 122, 1049-1061. Escher A., Watt, W. S. (1976) Geology of Greenland, Grønlands Geologiske undersøgelse. Fontorbe G., De La Rocha C.L., Chapman H.J. and Bickle M.J. (2013) The silicon isotopic composition of the Ganges and its tributaries. Earth and Planetary Science Letters 381, 21-30.

Frings P.J., Clymans W., Fontorbe G., De La Rocha C. and Conley D.J. (2016) The continental Si cycle and its impact on the ocean Si isotope budget. Chemical Geology 425, 12-36.

Gaillardet J., Dupré B., Louvat P. and Allègre C.J. (1999) Global silicate weathering and $\mathrm{CO} 2$ consumption rates deduced from the chemistry of large rivers. Chemical Geology 159, 3-30. Geilert S., Vroon P.Z., Roerdink D.L., Van Cappellen P. and van Bergen M.J. (2014) Silicon isotope fractionation during abiotic silica precipitation at low temperatures: Inferences from flow-through experiments. Geochim. Cosmochim. Acta 142, 95-114.

Georg R.B., Reynolds B.C., Frank M. and Halliday A.N. (2006) New sample preparation techniques for the determination of Si isotopic compositions using MC-ICPMS. Chemical Geology 235, 95-104. Georg R.B., Reynolds B.C., West A.J., Burton K.W. and Halliday A.N. (2007) Silicon isotope variations accompanying basalt weathering in Iceland. Earth and Planetary Science Letters 261, 476-490. Georg R.B., Zhu C., Reynolds B.C. and Halliday A.N. (2009) Stable silicon isotopes of groundwater, feldspars, and clay coatings in the Navajo Sandstone aquifer, Black Mesa, Arizona, USA. Geochim. Cosmochim. Acta 73, 2229-2241.

Graly J., Harrington J. and Humphrey N. (2017) Combined diurnal variations of discharge and hydrochemistry of the Isunnguata Sermia outlet, Greenland Ice Sheet. The Cryosphere 11, 1131-1140. Graly J.A., Humphrey N.F., Landowski C.M. and Harper J.T. (2014) Chemical weathering under the Greenland Ice Sheet. Geology 42, 551-554.

Harper J.T. and Humphrey N.F. (1995) Borehole video analysis of a temperate glacier' englacial and subglacial structure: Implications for glacier flow models. Geology 23, 901-904.

Hawkings J., Wadham J., Tranter M., Telling J., Bagshaw E., Beaton A., Simmons S.-L., Chandler D., Tedstone A. and Nienow P. (2016) The Greenland Ice Sheet as a hot spot of phosphorus weathering and export in the Arctic. Global Biogeochemical Cycles 30, 191-210.

Hawkings J.R., Hatton J.E., Hendry K.R., de Souza G.F., Wadham J.L., Ivanovic R., Kohler T.J., Stibal M., Beaton A., Lamarche-Gagnon G., Tedstone A., Hain M.P., Bagshaw E., Pike J. and Tranter M. (2018) The silicon cycle impacted by past ice sheets. Nature Communications $\mathbf{9}, 3210$.

Hawkings J.R., Wadham J.L., Benning L.G., Hendry K.R., Tranter M., Tedstone A., Nienow P. and Raiswell R. (2017) Ice sheets as a missing source of silica to the polar oceans. Nature Communications 8, 14198.

Hawkings J.R., Wadham J.L., Tranter M., Lawson E., Sole A., Cowton T., Tedstone A.J., Bartholomew I., Nienow P., Chandler D. and Telling J. (2015) The effect of warming climate on nutrient and solute export from the Greenland Ice Sheet. Geochemical Perspectives Letters, 94-104.

Hellmann R., Wirth R., Daval D., Barnes J.-P., Penisson J.-M., Tisserand D., Epicier T., Florin B. and Hervig R.L. (2012) Unifying natural and laboratory chemical weathering with interfacial dissolutionreprecipitation: A study based on the nanometer-scale chemistry of fluid-silicate interfaces. Chemical Geology 294-295, 203-216.

Hendry K. and Robinson L.F. (2012) The relationship between silicon isotope fractionation in sponges and silicic acid concentration.: Modern and core-top studies of biogenic opal. Geochim. Cosmochim. Acta 81, 1-12.

Henriksen N., Higgins, A. K., Kalsbeek, F., and Pulvertaft, T. C. R. (2009) Greenland From Archaean to Quaternary Descriptive Text to the 1995 Geological Map of Greenland, 1:2 500 000, Geol. Surv. Den. Greenl., Geological Survey of Denmark and Greenland, 2nd Edition ed, Copenhagen, pp. 9-116. Hindshaw R.S., Rickli J., Leuthold J., Wadham J. and Bourdon B. (2014) Identifying weathering sources and processes in an outlet glacier of the Greenland Ice Sheet using Ca and Sr isotope ratios. Geochim. Cosmochim. Acta 145, 50-71. 
Hoffman M.J., Catania G.A., Neumann T.A., Andrews L.C. and Rumrill J.A. (2011) Links between acceleration, melting, and supraglacial lake drainage of the western Greenland Ice Sheet. Journal of Geophysical Research: Earth Surface 116.

Hughes H.J., Delvigne C., Korntheuer M., de Jong J., André L. and Cardinal D. (2011) Controlling the mass bias introduced by anionic and organic matrices in silicon isotopic measurements by MC-ICPMS. Journal of Analytical Atomic Spectrometry 26, 1892.

Kohler T.J., Zarsky J.D., Yde J.C., Lamarche-Gagnon G., Hawkings J.R., Tedstone A.J., Wadham J.L., Box J.E., Beaton A.D. and Stibal M. (2017) Carbon dating reveals a seasonal progression in the source of particulate organic carbon exported from the Greenland Ice Sheet. Geophysical Research Letters 44, 6209-6217.

Lawson E.C., Wadham J.L., Tranter M., Stibal M., Lis G.P., Butler C.E.H., Laybourn-Parry J., Nienow P., Chandler D. and Dewsbury P. (2014) Greenland Ice Sheet exports labile organic carbon to the Arctic oceans. Biogeosciences 11, 4015-4028.

Lin I.J. and Somasundaran P. (1972) Alterations in properties of samples during their preparation by grinding. Powder Technology 6, 171-179.

Mair D., Willis I., Fischer U.H., Hubbard B., Nienow P. and Hubbard A. (2004) Hydrological controls on patterns of surface, internal and basal motion during three "spring events": Haut Glacier d'Arolla, Switzerland. Journal of Glaciology 49, 555-567.

Michaud A.B., Skidmore M.L., Mitchell A.C., Vick-Majors T.J., Barbante C., Turetta C., vanGelder W. and Priscu J.C. (2016) Solute sources and geochemical processes in Subglacial Lake Whillans, West Antarctica. Geology 44, 347-350.

Nienow P. (2014) The plumbing of Greenland's ice. Nature 514, 38.

Nienow P., Sharp M. and Willis I.C. (1998) Seasonal changes in the morphology of the subglacial drainage system, Haut Glacier d'Arolla, Switzerland. Earth Surface Processes and Landforms 23, 825843.

Nienow P.W., Sole A.J., Slater D.A. and Cowton T.R. (2017) Recent Advances in Our Understanding of the Role of Meltwater in the Greenland Ice Sheet System. Current Climate Change Reports 3, 330344.

Oelze M., von Blanckenburg F., Bouchez J., Hoellen D. and Dietzel M. (2015) The effect of Al on Si isotope fractionation investigated by silica precipitation experiments. Chemical Geology 397, 94-105. Opfergelt S., Burton K.W., Pogge von Strandmann P.A.E., Gislason S.R. and Halliday A.N. (2013) Riverine silicon isotope variations in glaciated basaltic terrains: Implications for the Si delivery to the ocean over glacial-interglacial intervals. Earth and Planetary Science Letters 369-370, 211-219. Reynolds B.C., Aggarwal J., André L., Baxter D., Beucher C., Brzezinski M.A., Engström E., Georg R.B., Land M., Leng M.J., Opfergelt S., Rodushkin I., Sloane H.J., van den Boorn S.H.J.M., Vroon P.Z. and Cardinal D. (2007) An inter-laboratory comparison of Si isotope reference materials. Journal of Analytical Atomic Spectrometry 22, 561-568.

Sauer D., Saccone L., Conley D.J., Herrmann L. and Sommer M. (2006) Review of methodologies for extracting plant-available and amorphous Si from soils and aquatic sediments. Biogeochemistry $\mathbf{8 0}$, 89-108.

Savage P.S., Georg R.B., Armytage R.M.G., Williams H.M. and Halliday A.N. (2010) Silicon isotope homogeneity in the mantle. Earth and Planetary Science Letters 295, 139-146.

Savage P.S., Georg R.B., Williams H.M. and Halliday A.N. (2013) Silicon isotopes in granulite xenoliths: Insights into isotopic fractionation during igneous processes and the composition of the deep continental crust. Earth and Planetary Science Letters 365, 221-231.

Stevenson E.I., Fantle M.S., Das S.B., Williams H.M. and Aciego S.M. (2017) The iron isotopic composition of subglacial streams draining the Greenland ice sheet. Geochim. Cosmochim. Acta 213, 237-254.

Telling J., Boyd E.S., Bone N., Jones E.L., Tranter M., MacFarlane J.W., Martin P.G., Wadham J.L., Lamarche-Gagnon G., Skidmore M.L., Hamilton T.L., Hill E., Jackson M. and Hodgson D.A. (2015) Rock comminution as a source of hydrogen for subglacial ecosystems. Nature Geoscience 8, 851. 
Tranter M., Sharp M.J., Lamb H.R., Brown G.H., Hubbard B.P. and Willis I.C. (2002) Geochemical weathering at the bed of Haut Glacier d'Arolla, Switzerland - A new model. Hydrological Processes 16, 959-993.

Tranter M. and Wadham J.L. (2014) 7.5 - Geochemical Weathering in Glacial and Proglacial Environments A2 - Holland, Heinrich D, in: Turekian, K.K. (Ed.), Treatise on Geochemistry (Second Edition). Elsevier, Oxford, pp. 157-173.

Wadham J.L., Tranter M., Skidmore M., Hodson A.J., Priscu J., Lyons W.B., Sharp M., Wynn P. and Jackson M. (2010) Biogeochemical weathering under ice: Size matters. Global Biogeochemical Cycles 24.

Walker J.C.G., Hays P.B. and Kasting J.F. (1981) A negative feedback mechanism for the long-term stabilization of Earth's surface temperature. Journal of Geophysical Research: Oceans 86, 9776-9782. Yde J.C., Knudsen N.T., Hasholt B. and Mikkelsen A.B. (2014) Meltwater chemistry and solute export from a Greenland Ice Sheet catchment, Watson River, West Greenland. Journal of Hydrology 519, 2165-2179.

Ziegler K., Chadwick O.A., Brzezinski M.A. and Kelly E.F. (2005) Natural variations of $\delta 30 S i$ ratios during progressive basalt weathering, Hawaiian Islands. Geochim. Cosmochim. Acta 69, 4597-4610. Ziegler K., Chadwick O.A., Kelly E.F. and Brzezinski M.A. (2002) The $\delta 30$ Si values of soil weathering profiles: Indicators of Si pathways at the lithosphere/hydro (bio) sphere interface. Geochim. Cosmochim. Acta 66, A881.

Table 1: Hydrological comparison of two studied catchments. Qwt $=$ discharge weighted mean, $\mathrm{D}: \mathrm{M}=$ divalent to monovalent ion ratio, $\mathrm{DSi}=$ Dissolved silicate, $\mathrm{ASi}=$ Amorphous silica .

\begin{tabular}{|l|l|l|}
\hline & Kiattuut Sermia (2013) & $\begin{array}{l}\text { Leverett Glacier } \\
(2015)\end{array}$ \\
\hline Mean Q $\left(\mathrm{m}^{3} \mathrm{~S}^{-1}\right)$ & $22.80^{+}$ & 85.35 \\
\hline Total Q $\left(\mathrm{km}^{3}\right)$ & $0.22^{+}$ & 1.45 \\
\hline Qwt Sus. Sediment $\left(\mathrm{g} \mathrm{L}^{-1}\right)$ & $0.12^{+}$ & 0.87 \\
\hline Qwt pH & 9.09 & 8.63 \\
\hline Qwt EC $\left(\mu \mathrm{S} \mathrm{cm}{ }^{-1}\right)$ & $26.66^{+}$ & 12.25 \\
\hline Qwt D:M $(\mu \mathrm{eq})$ & 6.91 & 1.36 \\
\hline Qwt DSi $(\mu \mathrm{M})$ & 22.18 & 20.76 \\
\hline Qwt ASi $(\mu \mathrm{M})$ & 9.87 & 205.78 \\
\hline Qwt $\delta^{30} \mathrm{DSi}(\%)$ & 0.41 & -0.25 \\
\hline Qwt $\delta^{30} \mathrm{ASi}(\%)$ & -0.47 & -0.22 \\
\hline Bulk Rock $\delta^{30} \mathrm{Si}(\%)$ & -0.18 & $0.00^{+}$ \\
\hline
\end{tabular}

${ }^{+}$Data previously published by Hawkings et al. (2016).

Figure 1: Location of Kiattuut Sermiat and Leverett Glacier, from Hawkings et al. (2016). Water samples were collected at the locations marked in black from proglacial streams, as in Lawson et al. (2014) and Hawkings et al. (2016). Hydrological monitoring was completed at points of stable bedrock (white markers).

Figure 2: Hydrological and Geochemical Time series for LG (black, A) and KS (red, B). Vertical black shading in A shows outburst events recorded during the melt season (Kohler et al., 2017) and vertical red shading in B shows the "Spring Event" at KS (Hawkings et al., 2016).

Figure 3: Major ion ratio time series. Ratio of Divalent/Monovalent ions (D:M) Differences in the seasons (i.e. Late and Early Season) are defined by differences in hydrological and geochemical data in the proglacial river. 
Figure 4: Na-normalised molar ratio mixing diagrams. Silicate and carbonate endmembers taken from Gaillardet et al. (1999) and references within, using data from small rivers draining one single lithology.

Figure 5: Silicon isotope composition results. A) The relationship between $\delta^{30} \mathrm{DSi}$ and D:M ion ratio. B) $\delta^{30} \mathrm{DSi}$ and discharge for both catchments. C and D) Time series of $\delta^{30} \mathrm{DSi}$ and $\delta^{30} \mathrm{ASi}$ for KS and LG. Vertical blue shading in $\mathrm{C}$ indicates opening of the subglacial drainage system ("Spring Event", Hawkings et al. (2016)) and outburst events in D. Bulk bedrock $\delta^{30} \mathrm{Si}$ is indicated by the horizontal dashed line, with the shading representing 2SD. All error bars represent 2SD of external errors $\left(0.08\right.$ for $\delta^{30} \mathrm{DSi}$ and 0.14 for $\left.\delta^{30} \mathrm{ASi}\right)$.

Figure 6: Diagram to illustrate conceptual model of subglacial hydrology development. Simplified development of subglacial hydrology at LG as the melt season progresses. Panel A represents processes during the Early season of LG (before the first outburst event), B represents the system after the first outburst event and subglacial water influences the proglacial stream chemistry, and $\mathrm{C}$ represents the system during the late season once the snowline has retreated further and outburst events occur more often. The smaller size of KS limits the subglacial hydrology development to $\mathrm{A}$ and $\mathrm{B}$, without the connection of isolated subglacial water by supraglacial lake drainage.

Figure 7: Major ion relationship plots. A) $\mathrm{Ca}^{2+}+\mathrm{Mg}^{2+}$ versus $\mathrm{SO}_{4}{ }^{2-} \mathrm{B}$ ) $\mathrm{Ca}^{2+}+\mathrm{Mg}^{2+}$ versus $\mathrm{HCO}_{3}{ }^{-} \mathrm{C}$ ) $\mathrm{HCO}_{3}{ }^{-}$versus $\mathrm{SO}_{4}{ }^{2-}$. Early Season at $\mathrm{KS}$ is defined as before the subglacial system connected (Day 157, Hawkings et al. (2016)), Transition Period is the hydrologically unique period after the subglacial connection and Late Season is post Day 169. Early season at LG is defined at prior to first outburst event/subglacial connectivity at day 170 and late season is defined as day 170 onwards. Grey dashed lines show main relationships found by Tranter et al. (2002) when studying an Alpine valley glacier. The table outlines the regression slopes, intercepts and $\mathrm{R}^{2}$ values for each relationship.

Figure 8: Modelled Percentage ASi required for measured $\delta^{30} \mathrm{DSi}$ composition. Panels A and B show the calculated $f_{a}$ values according to Equation 7, with A (black) showing the time series at LG and B (red) showing the time series at KS. $\varepsilon$ values represent the varying fractionation factors used in the model. Panels $\mathrm{C}(\mathrm{LG})$ and $\mathrm{D}(\mathrm{KS})$ show the concentration of ASi required to produce the measured DSi, compared to the measured ASi concentrations over the melt season.

Supplementary Figure 1: Estimated lake Residence Time at KS. Residence time of the proglacial lake at KS estimated by calculating the turnover rate of the lake using the estimated water volume of the lake and river discharge.

Supplementary Figure 2: Silicon three Isotope plot. All samples analysed during the study are included with red dashed lines showing the $95 \%$ prediction band and grey lines showing the 95\% confidence band. The black regression line has a gradient of $0.5118\left(\mathrm{p}<0.0001, \mathrm{R}^{2}=0.9946\right)$, showing mass dependent fractionation

Supplementary Figure 3: Relationship between $\delta^{30} \mathrm{DSi}$ composition and saturation index of amorphous silica. Saturation indices calculated using Geochemists Workbench Software and plotted against $\delta^{30} \mathrm{DSi}$ for both catchments. Data has been split into the defined hydrological periods of the melt season to show the temporal trend.

Supplementary Figure 4: Comparison of geochemical data with previously published data at LG. Records of discharge, D:M ratio and $\mathrm{SO}_{4}{ }^{2-}$ from LG in 2009 (Hindshaw et al., 2014) and 2015 (this study).

Supplementary Figure 5: Sulphate Mass Fraction Timeseries. Calculated SMF for KS and LG over the melt season, with the seasons defined by hydrogeochemical data. 
876 Supplementary Figure 6: Relationship between SPM concentrations and dissolved silicon 877 isotope composition. 
1 Supplementary Table 1: Selected ionic concentrations from Leverett Glacier 2015, corresponding to timepoints in which silicon isotope measurements 2 were made.

\begin{tabular}{|c|c|c|c|c|c|c|c|c|c|c|}
\hline $\begin{array}{l}\text { Decimal } \\
\text { Day }\end{array}$ & $\begin{array}{l}\mathrm{Na}^{+} \\
(\mu \mathrm{eq})\end{array}$ & $\begin{array}{l}K^{+} \\
(\mu e q)\end{array}$ & $\begin{array}{l}\mathrm{Mg}^{2+} \\
(\mu e q)\end{array}$ & $\begin{array}{l}\mathrm{Ca}^{2+} \\
(\mu e q)\end{array}$ & $\begin{array}{l}\mathrm{Al}^{3+} \\
(\mu e q)\end{array}$ & 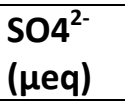 & $\begin{array}{l}\mathrm{NO3}^{-} \\
\text {( } \mu \mathrm{eq})\end{array}$ & 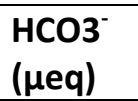 & $\begin{array}{l}F^{-} \\
(\mu e q)\end{array}$ & $\begin{array}{l}\mathrm{Cl}^{-} \\
(\mu \mathrm{eq})\end{array}$ \\
\hline 128.4 & 53.84 & 36.79 & 98.64 & 349.25 & - & 229.58 & 0.35 & 271.80 & 2.11 & 30.98 \\
\hline 135.4 & 41.04 & 26.68 & 61.27 & 215.01 & 1.66 & 118.64 & 0.39 & 200.01 & 0.93 & 20.05 \\
\hline 140.8 & 56.16 & 38.59 & 41.59 & 126.20 & 4.06 & 75.20 & 0.44 & 256.49 & 1.22 & 37.1 \\
\hline 145.4 & 64.46 & 39.38 & 73.43 & 252.03 & - & 117.65 & 0.35 & 286.19 & 1.53 & 19.94 \\
\hline 148.4 & 46.21 & 30.20 & 52.09 & 183.94 & 5.59 & 88.86 & 0.33 & 203.98 & 1.08 & 1487 \\
\hline 153.4 & 88.11 & 48.69 & 52.26 & 262.81 & 2.03 & 161.33 & 0.15 & 260.72 & 3.14 & 24.90 \\
\hline 160.4 & 67.06 & 38.06 & 42.93 & 220.05 & 12.62 & 122.06 & 0.31 & 222.43 & 1.90 & 18.24 \\
\hline 165.4 & 49.13 & 25.40 & 24.07 & 123.15 & 2.50 & 59.27 & 0.08 & 145.82 & 1.18 & 14.58 \\
\hline 171.4 & 55.46 & 28.05 & 20.89 & 102.54 & 1.56 & 47.75 & 0.18 & 143.14 & 1.07 & 12.95 \\
\hline 174.7 & 44.83 & 16.96 & 13.71 & 58.35 & 1.98 & 24.71 & 0.16 & 87.43 & 1.31 & 18.68 \\
\hline 178.4 & 65.73 & 29.85 & 19.74 & 87.76 & 20.78 & 45.21 & 0.08 & 148.22 & 1.43 & 7.25 \\
\hline 183.4 & 66.15 & 37.57 & 20.31 & 83.19 & 22.94 & 37.66 & 0.16 & 159.93 & 1.54 & 6.24 \\
\hline 186.4 & 50.78 & 24.61 & 14.56 & 65.33 & - & 26.79 & 0.19 & 119.10 & 0.92 & 6.34 \\
\hline 189.4 & 47.50 & 20.29 & 13.47 & 60.33 & 139.81 & 23.70 & 0.15 & 111.80 & 0.94 & 3.48 \\
\hline 191.4 & 48.82 & 22.10 & 15.99 & 75.44 & 15.09 & 31.13 & 0.18 & 124.23 & 0.98 & 4.05 \\
\hline 196.3 & 36.56 & 16.10 & 13.40 & 65.53 & 16.01 & 25.13 & 0.13 & 99.53 & 0.85 & 4.59 \\
\hline 200.4 & 44.98 & 20.55 & 12.40 & 73.24 & 61.02 & 38.46 & 0.09 & 105.85 & 0.98 & 4.83 \\
\hline 207.4 & 52.17 & 23.93 & 13.88 & 89.36 & 58.96 & 45.75 & 0.10 & 128.46 & 1.46 & 2.53 \\
\hline 208.4 & 59.20 & 26.68 & 14.14 & 106.63 & 69.25 & 54.22 & 0.10 & 146.83 & 1.35 & 3.09 \\
\hline 210.3 & 53.30 & 24.34 & 16.37 & 95.11 & 78.68 & 47.20 & 0.12 & 136.60 & 1.38 & 2.64 \\
\hline
\end{tabular}

3 
7 Supplementary Table 2: Selected ionic concentrations from Kiattuut Sermiat 2013, corresponding to timepoints in which silicon isotope measurements 8 were made.

\begin{tabular}{|c|c|c|c|c|c|c|c|c|c|c|}
\hline Decimal Day & $\begin{array}{l}\mathrm{Na}^{+} \\
(\mu \mathrm{eq})\end{array}$ & $\begin{array}{l}K^{+} \\
(\mu e q)\end{array}$ & $\begin{array}{l}\mathrm{Mg}^{2+} \\
(\mu e q)\end{array}$ & $\begin{array}{l}\mathrm{Ca}^{2+} \\
(\mu e q)\end{array}$ & $\begin{array}{l}\mathrm{Al}^{3+} \\
(\mu \mathrm{eq})\end{array}$ & 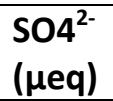 & $\begin{array}{l}\mathrm{NO3}^{-} \\
\text {( } \mu \mathrm{eq})\end{array}$ & 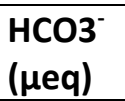 & 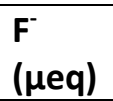 & $\begin{array}{l}\mathrm{Cl}^{-} \\
(\mu \mathrm{eq})\end{array}$ \\
\hline 111.59 & 47.92 & 29.14 & 63.53 & 442.50 & 5.10 & 66.13 & 0.07 & 477.37 & 19.01 & 24.51 \\
\hline 124.48 & 45.32 & 28.32 & 53.57 & 404.70 & - & 70.94 & 0.23 & 417.08 & 18.15 & 22.96 \\
\hline 139.50 & 45.22 & 29.46 & 54.62 & 378.04 & - & 75.97 & 0.23 & 387.05 & 17.65 & 23.91 \\
\hline 149.50 & 46.24 & 29.47 & 56.42 & 397.38 & - & 82.29 & 0.32 & 398.28 & 18.39 & 26.13 \\
\hline 150.50 & 42.33 & 27.46 & 51.81 & 373.51 & 6.64 & 82.68 & 0.32 & 363.79 & 19.03 & 25.91 \\
\hline 155.52 & 42.37 & 27.34 & 49.55 & 358.36 & 7.24 & 73.93 & 0.30 & 359.86 & 16.12 & 24.21 \\
\hline 159.50 & 36.44 & 24.16 & 42.55 & 296.01 & - & 59.01 & 0.26 & 303.08 & 12.14 & 21.92 \\
\hline 162.63 & 30.68 & 21.43 & 36.56 & 264.80 & - & 50.45 & 0.26 & 268.78 & 11.86 & 19.41 \\
\hline 170.90 & 24.47 & 18.84 & 28.39 & 224.87 & 17.44 & 29.96 & 0.19 & 251.22 & 9.11 & 12.73 \\
\hline 172.68 & 22.96 & 18.03 & 27.04 & 224.71 & 19.92 & 26.37 & 0.16 & 244.61 & 8.57 & 11.29 \\
\hline 178.50 & 21.14 & 17.23 & 26.89 & 227.25 & - & 22.92 & 0.15 & 250.96 & 7.44 & 9.39 \\
\hline 181.50 & 19.95 & 16.37 & 25.15 & 226.12 & - & 22.27 & 0.12 & 246.50 & 8.09 & 9.24 \\
\hline 194.52 & 18.88 & 14.46 & 25.91 & 218.87 & - & 20.43 & 0.09 & 240.61 & 8.43 & 7.47 \\
\hline 205.54 & 15.01 & 11.96 & 21.04 & 179.89 & - & 14.43 & 0.08 & 200.92 & 6.53 & 4.99 \\
\hline 207.50 & 13.18 & 10.44 & 17.51 & 147.3 & - & 13.76 & 0.09 & 161.89 & 6.71 & 4.99 \\
\hline 212.53 & 14.65 & 11.22 & 19.34 & 181.91 & 13.53 & 15.05 & 0.06 & 198.67 & 7.41 & 5.26 \\
\hline 220.63 & 13.56 & 10.52 & 17.92 & 167.17 & 11.73 & 15.04 & 0.05 & 180.46 & 7.82 & 5.17 \\
\hline 221.6 & 13.14 & 11.01 & 16.93 & 164.53 & - & 14.15 & 0.03 & 191.17 & 6.68 & 4.57 \\
\hline
\end{tabular}

9 
Supplementary Table 3: Summary of Kiattuut Sermiat silicon isotope results from 2013.

\begin{tabular}{|c|c|c|c|c|c|c|c|c|c|c|}
\hline $\begin{array}{c}\text { Decimal } \\
\text { Day }\end{array}$ & $\begin{array}{c}\text { Discharge } \\
\left(\mathrm{m}^{3} \mathrm{~s}^{-3}\right)\end{array}$ & $\mathrm{pH}$ & $\begin{array}{l}\text { Suspended } \\
\text { Sediment } \\
\left(\mathrm{g} \mathrm{L}^{-1}\right)\end{array}$ & $\begin{array}{c}\text { DSi } \\
(\mu \mathrm{M})\end{array}$ & $\begin{array}{c}\delta^{30} \mathrm{DSi} \\
(\%)\end{array}$ & $\begin{array}{c}\delta^{30} \mathrm{DSi} \\
\text { error } * \\
(2 \sigma S D \% \text { o })\end{array}$ & $\begin{array}{c}\mathrm{ASi} \\
\text { (wt\%) }\end{array}$ & $\begin{array}{c}\delta^{30} \mathrm{ASi} \\
(\% \circ)\end{array}$ & $\begin{array}{c}\delta^{30} \mathrm{ASi} \\
\text { error } * \\
(2 \sigma S D \% \circ) \\
\end{array}$ & $\begin{array}{c}\text { Monovalent/ } \\
\text { Divalent ions } \\
\left(\mu e q \mathrm{~L}^{-1}\right)\end{array}$ \\
\hline 111.6 & 0.7 & 8.29 & 0.04 & 40.59 & 1.01 & 0.05 & & & & 6.57 \\
\hline 124.5 & 2.6 & 7.79 & 0.04 & 39.29 & 0.79 & 0.18 & & & & 6.22 \\
\hline 139.5 & 3.6 & 8.08 & 0.11 & 36.60 & 0.71 & 0.08 & & & & 5.79 \\
\hline 149.5 & 7.0 & 7.94 & 0.25 & 38.45 & & & 0.24 & -0.56 & 0.05 & 5.99 \\
\hline 150.5 & 7.1 & 8.02 & 0.15 & 36.14 & 0.69 & 0.11 & & & & 6.09 \\
\hline 155.5 & 17.9 & 8.23 & 0.16 & 34.62 & 0.64 & 0.09 & & & & 5.85 \\
\hline 159.5 & 34.5 & 8.86 & 0.18 & 28.33 & & & 0.37 & -0.54 & 0.05 & 5.59 \\
\hline 162.6 & 27.6 & 8.85 & 0.13 & 26.76 & 0.47 & 0.10 & & & & 5.78 \\
\hline 170.9 & 34.4 & 9.19 & 0.13 & 22.70 & & & 0.05 & -0.38 & 0.07 & 6.05 \\
\hline 172.7 & 33.3 & 9.25 & 0.11 & 21.84 & 0.26 & 0.11 & & & & 6.14 \\
\hline 178.5 & 18.5 & 9.38 & 0.13 & 20.69 & & & 0.36 & -0.42 & 0.06 & 6.62 \\
\hline 181.5 & 19.5 & 9.38 & 0.12 & 20.90 & 0.25 & 0.11 & & & & 6.92 \\
\hline 194.5 & 43.3 & 9.46 & 0.10 & 20.68 & 0.38 & 0.08 & 0.16 & -0.48 & 0.06 & 7.34 \\
\hline 205.5 & 42.9 & 9.08 & 0.09 & 16.49 & 0.57 & 0.02 & & & & 7.45 \\
\hline 207.5 & 37.7 & 9.08 & 0.10 & 16.00 & & & 0.26 & -0.42 & 0.06 & 6.98 \\
\hline 212.5 & 36.2 & 9.13 & 0.10 & 16.49 & 0.41 & 0.09 & 0.24 & & & 7.78 \\
\hline 220.6 & 29.9 & 9.48 & 0.08 & 16.79 & 0.16 & 0.14 & & & & 7.67 \\
\hline 221.6 & 29.9 & 9.34 & 0.09 & 15.92 & & & 0.18 & -0.56 & 0.05 & 7.67 \\
\hline
\end{tabular}

13 *Propagated internal error $(2 \sigma \mathrm{SD}, \%$ ) 


\begin{tabular}{|c|c|c|c|c|c|c|c|c|c|c|}
\hline $\begin{array}{c}\text { Decimal } \\
\text { Day }\end{array}$ & $\begin{array}{c}\text { Discharge } \\
\left(\mathrm{m}^{3} \mathrm{~s}^{-3}\right)\end{array}$ & $\mathrm{pH}$ & $\begin{array}{c}\text { Suspended } \\
\text { Sediment (g } \\
\left.\mathrm{L}^{-1}\right)\end{array}$ & $\begin{array}{c}\text { DSi } \\
(\mu \mathrm{M})\end{array}$ & $\begin{array}{c}\delta^{30} \text { DSi } \\
(\% \circ)\end{array}$ & $\begin{array}{c}\delta^{30} \mathrm{DSi} \\
\text { error * } \\
(2 \sigma S D \% \text { \%o }\end{array}$ & $\begin{array}{c}\text { ASi } \\
\text { (wt\%) }\end{array}$ & $\begin{array}{c}\delta^{30} \mathrm{ASi} \\
(\% \circ)\end{array}$ & $\begin{array}{c}\delta^{30} \mathrm{ASi} \\
\text { error * } \\
(2 \sigma \mathrm{SD} \% \text { \% })\end{array}$ & $\begin{array}{c}\text { Monovalent/ } \\
\text { Divalent ions } \\
\left(\mu \mathrm{eq} \mathrm{L}^{-1}\right)\end{array}$ \\
\hline 128.4 & - & 8.98 & - & 53.66 & 0.85 & 0.04 & - & - & - & 4.94 \\
\hline 135.4 & - & 7.88 & - & 36.01 & 0.87 & 0.04 & 0.85 & 0.05 & 0.05 & 4.08 \\
\hline 140.8 & - & 8.35 & - & 38.86 & - & & 1.41 & 0.21 & 0.03 & 3.42 \\
\hline 145.4 & - & 7.90 & - & 38.47 & 0.65 & 0.03 & 1.40 & -0.16 & 0.03 & 3.13 \\
\hline 148.4 & 5.4 & 7.72 & & 35.63 & - & - & - & - & - & 3.09 \\
\hline 153.4 & 13.0 & 7.85 & 0.54 & 37.00 & 0.66 & 0.04 & 1.03 & - & - & 2.30 \\
\hline 160.4 & 17.5 & 7.80 & 0.53 & 31.51 & 0.60 & 0.02 & 0.75 & - & - & 2.34 \\
\hline 165.4 & 25.1 & 7.64 & 0.56 & 24.13 & 0.37 & 0.03 & 0.86 & -0.19 & 0.03 & 1.98 \\
\hline 171.4 & 73.2 & 8.01 & 1.18 & 20.24 & 0.02 & 0.08 & 0.64 & - & - & 1.48 \\
\hline 174.7 & 90.0 & 7.63 & 0.72 & 15.05 & -0.23 & 0.02 & - & - & - & 1.17 \\
\hline 178.4 & 122.7 & 8.41 & 1.37 & 24.85 & -0.18 & 0.03 & 0.69 & -0.20 & 0.04 & 1.12 \\
\hline 183.4 & 215.1 & 9.18 & 2.09 & 27.69 & -0.52 & 0.02 & 0.39 & -0.15 & 0.03 & 1.00 \\
\hline 186.4 & 207.2 & 8.33 & 0.85 & 19.75 & -0.41 & 0.03 & 0.70 & - & - & 1.14 \\
\hline 189.4 & 294.5 & 8.76 & 0.97 & 17.79 & -0.41 & 0.03 & 0.83 & - & - & 1.09 \\
\hline 191.4 & 360.9 & 9.24 & 1.05 & 21.41 & -0.22 & 0.03 & 0.59 & -0.27 & 0.04 & 1.29 \\
\hline 196.3 & 230.1 & 8.58 & 0.66 & 16.29 & -0.55 & 0.04 & 0.64 & - & - & 1.50 \\
\hline 200.4 & 311.3 & 8.86 & 0.66 & 19.70 & -0.14 & 0.03 & 0.85 & -0.32 & 0.03 & 1.31 \\
\hline 207.4 & 301.9 & 9.53 & 0.70 & 22.02 & - & - & 0.54 & -0.16 & 0.04 & 1.36 \\
\hline 208.4 & 270.5 & 9.62 & 0.78 & 24.83 & -0.09 & 0.03 & 0.31 & - & - & 1.41 \\
\hline 210.3 & 236.3 & 9.51 & 0.83 & 23.63 & -0.06 & 0.03 & 0.97 & -0.11 & 0.03 & 1.44 \\
\hline
\end{tabular}

*Propagated internal error $(2 \sigma \mathrm{SD}, \%$ ) 


\begin{tabular}{|c|c|c|c|c|}
\hline & Up to Day 210 & After Day 210* & Total* & \\
\hline$Q(L)$ & $1.27 \times 10^{12}$ & $6.04 \times 10^{11}$ & $1.88 \times 10^{12}$ & 25 \\
\hline$\%$ of $Q$ for melt period & 67.8 & 32.2 & 100 & \\
\hline & & & & 26 \\
\hline DSi Flux ( $\mu \mathrm{Mol})$ & $2.65 \times 10^{13}$ & $1.26 \times 10^{13}$ & $3.90 \times 10^{13}$ & 27 \\
\hline ASi Flux ( $\mu \mathrm{Mol})$ & $2.65 \times 10^{14}$ & $1.25 \times 10^{14}$ & $3.90 \times 10^{14}$ & 28 \\
\hline Total Si Flux ( $\mu \mathrm{Mol})$ & $2.91 \times 10^{14}$ & $1.38 \times 10^{14}$ & $4.29 \times 10^{14}$ & \\
\hline $\begin{array}{l}\% \text { of DSi Flux for melt } \\
\text { period }\end{array}$ & 9.1 & 9.1 & 9.1 & $\begin{array}{l}29 \\
30\end{array}$ \\
\hline $\begin{array}{l}\% \text { of ASi Flux for melt } \\
\text { period }\end{array}$ & 90.9 & 90.9 & 90.9 & 31 \\
\hline Qwt $\delta^{30}$ DSi (\%o) & -0.25 & +2.20 & NA & 32 \\
\hline Qwt $\delta^{30}$ ASi (\%o) & -0.22 & -0.22 & NA & 33 \\
\hline Total $\delta^{30} \mathrm{Si}(\%)$ & -0.21 & +0.44 & 0.00 & \\
\hline
\end{tabular}

$35 *$ All calculated values, except for $Q$, based on the percentage of $Q$ measured before and after Day 210.

37 Supplementary Table 6: Details of ASi concentrations taken from selected proglacial debris in front of LG.

\begin{tabular}{|l|l|l|l|}
\hline Sample Number & Date of Collection & Location & ASi (\%) \\
\hline 1 & $30 / 5 / 2015$ & $\begin{array}{l}\text { N67 03.909 } \\
\text { W050 09. 795 }\end{array}$ & 0.02 \\
\hline 2 & $30 / 5 / 2015$ & $\begin{array}{l}\text { N67 03.912 } \\
\text { W050 09.789 }\end{array}$ & $>0.01$ \\
\hline 6 & $2 / 6 / 2105$ & $\begin{array}{l}\text { N67 03.758 } \\
\text { W050 12.093 }\end{array}$ & 0.01 \\
\hline
\end{tabular}




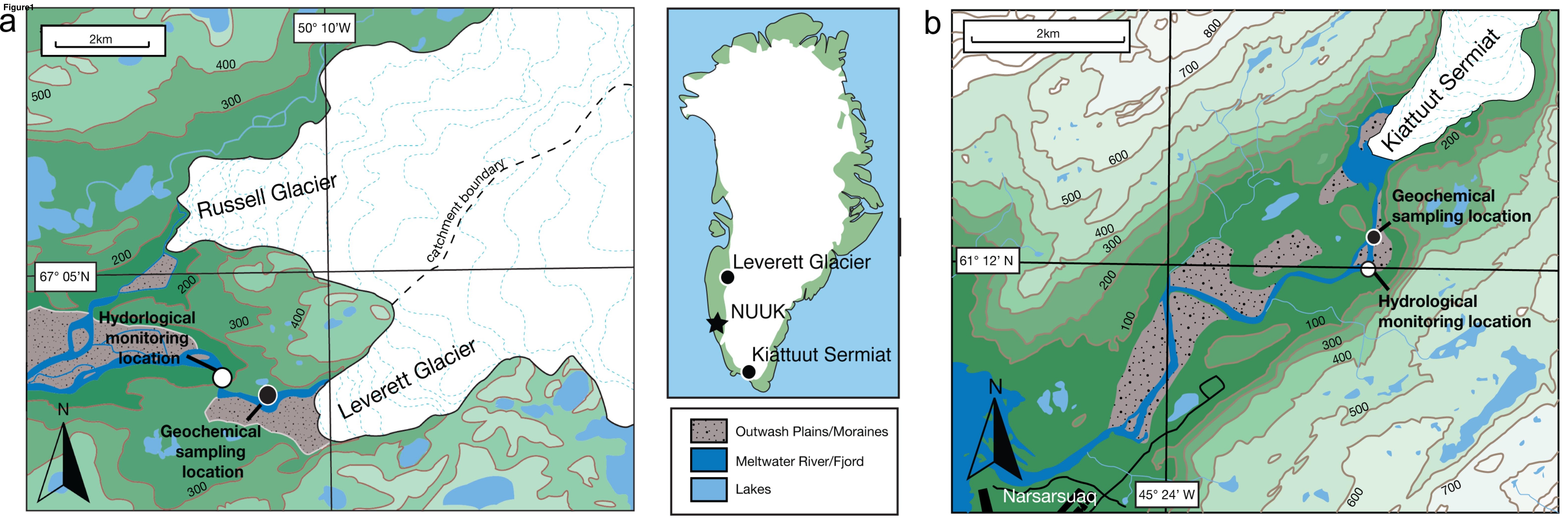



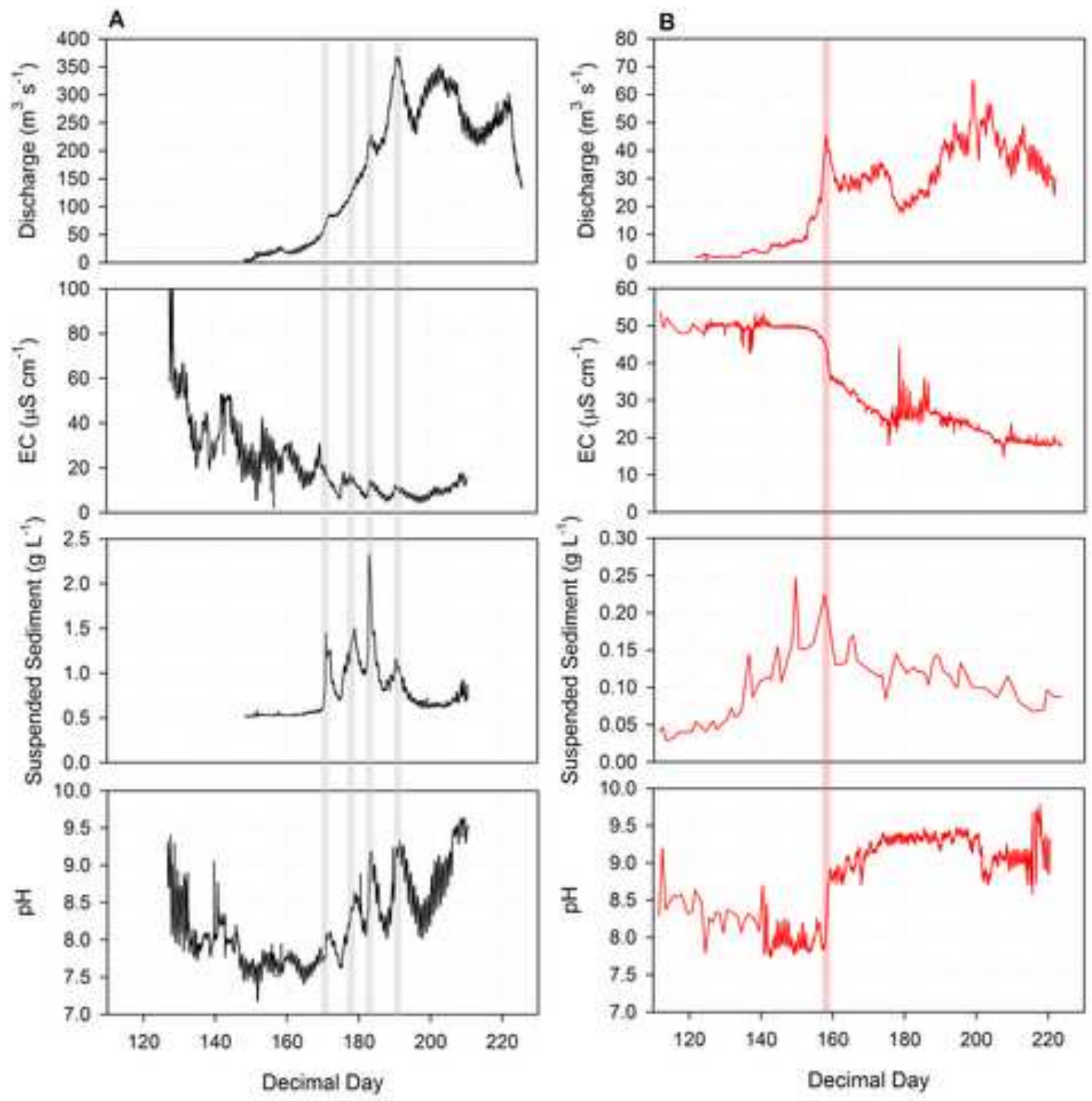

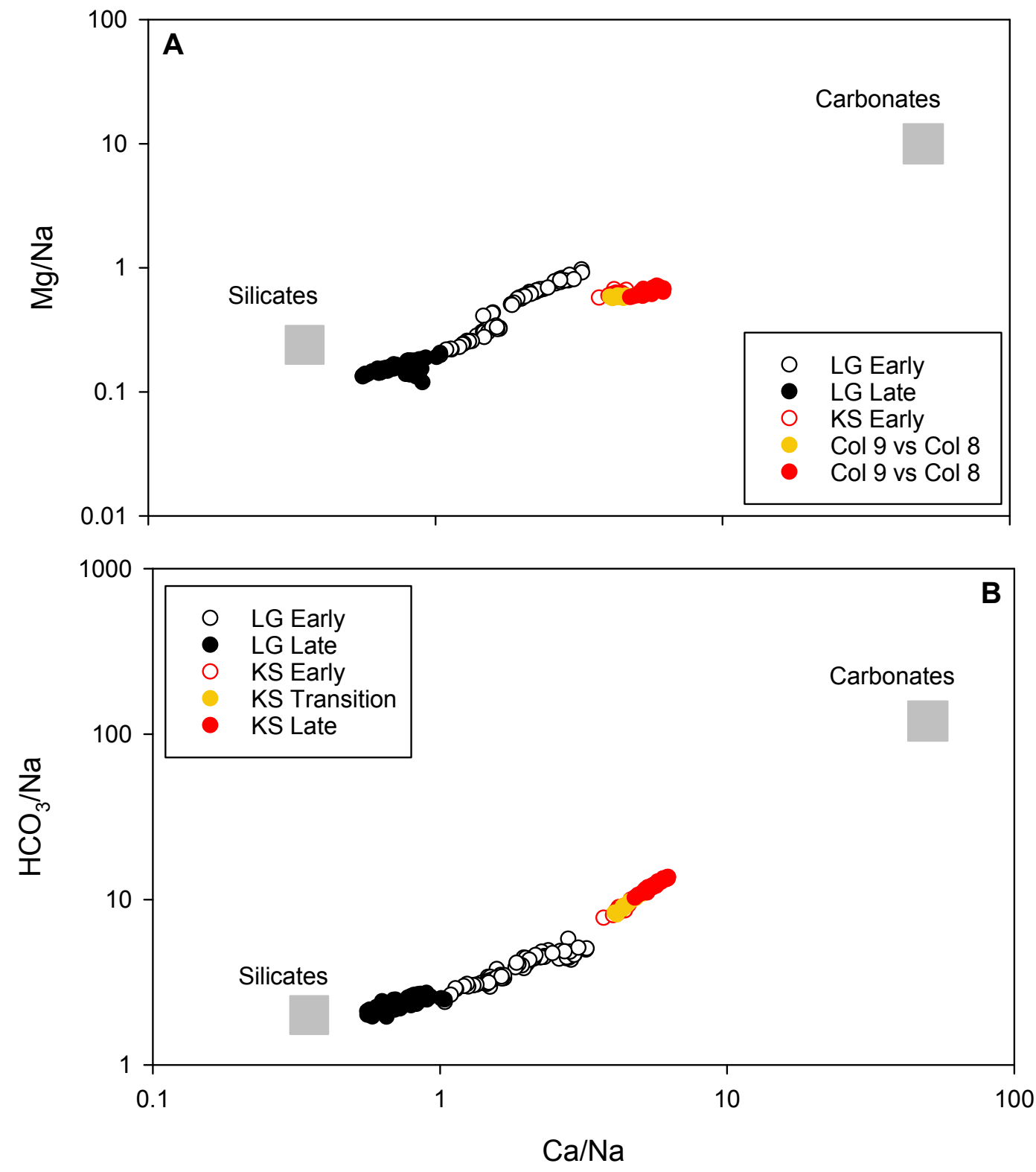
Figure5
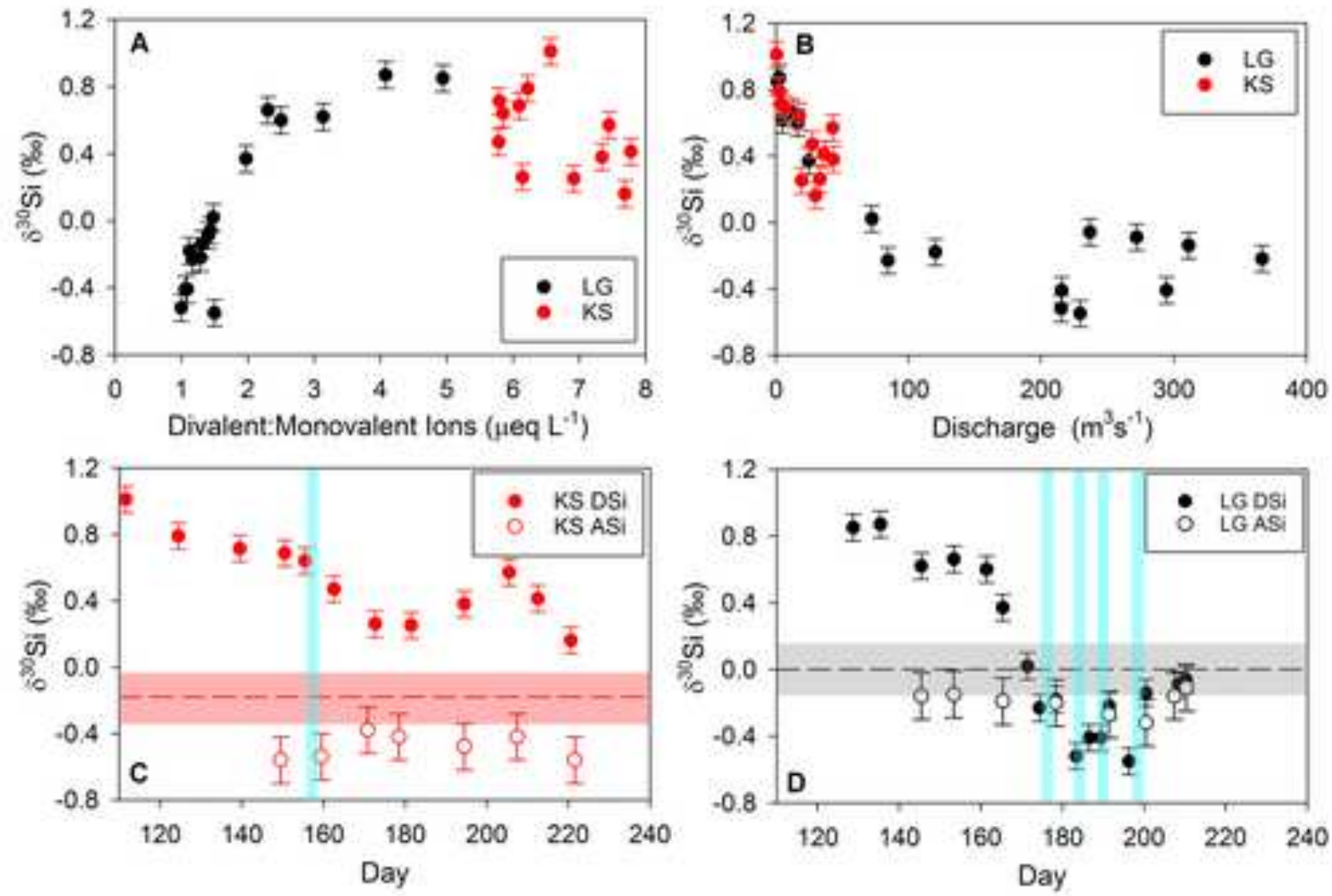

Click here to download high resolution image 


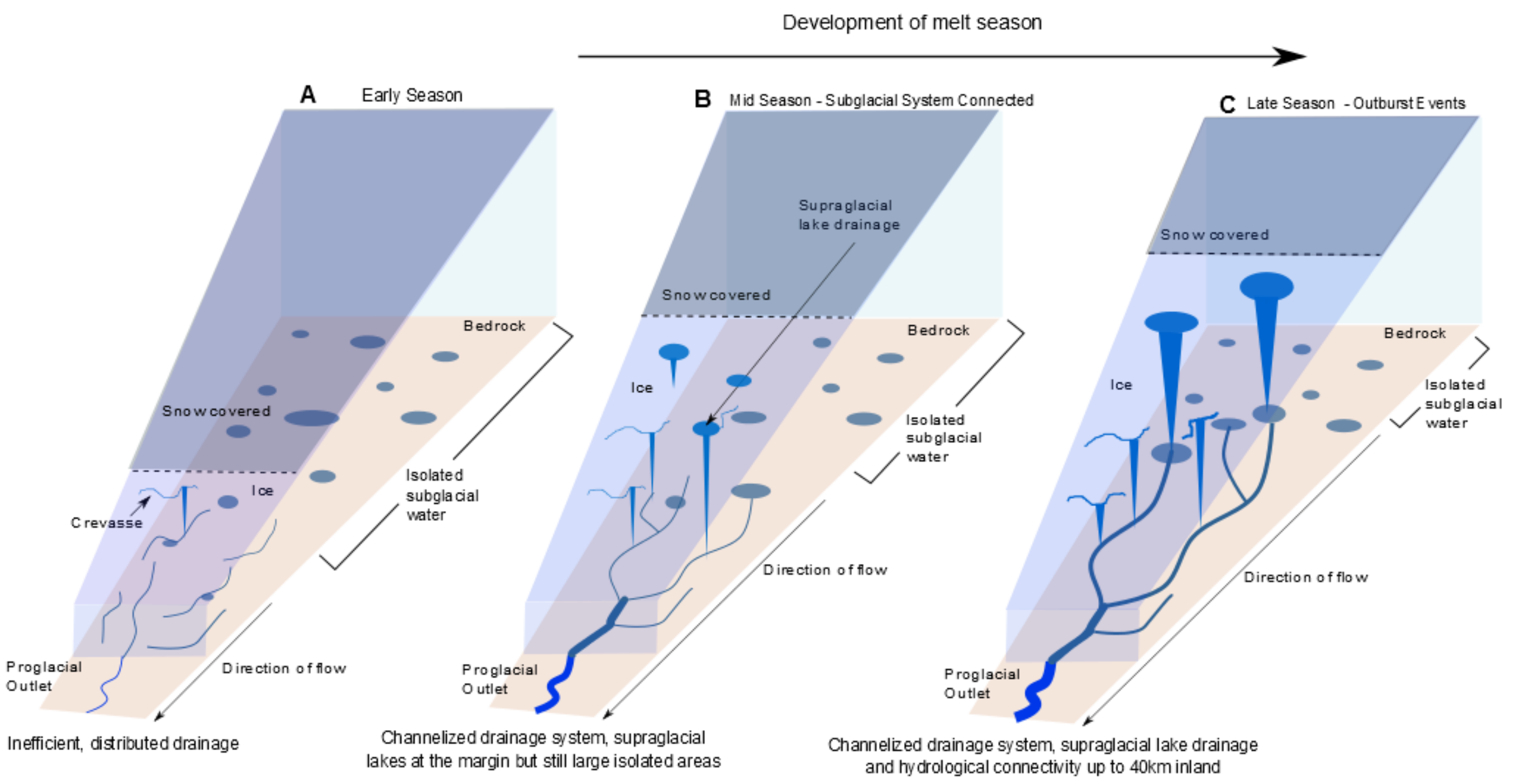




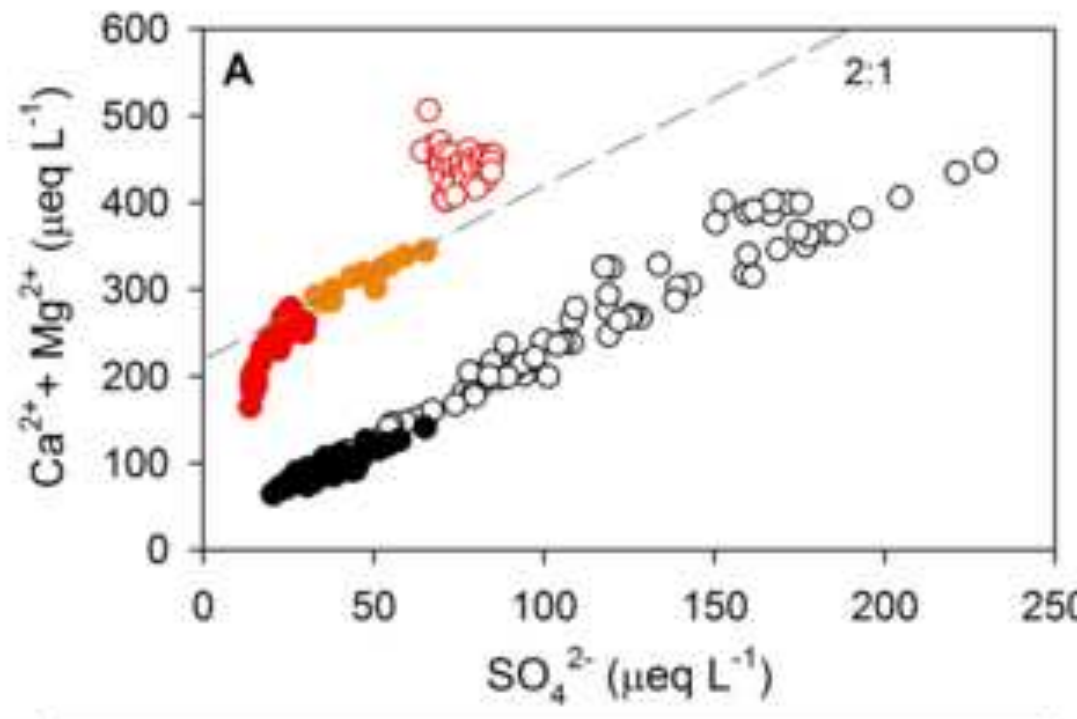

\begin{tabular}{|c|c|c|c|c|}
\hline & & $\mathrm{HCO}_{3} / \mathrm{SO}_{4}^{2}$ & $\begin{array}{c}\left(\mathrm{Ca}^{2+}+\mathrm{Mg}^{2+}\right) \\
/ \mathrm{SO}_{4}^{2}\end{array}$ & $\begin{array}{c}\left(\mathrm{Ca}^{2+}+\mathrm{Mg}^{2+}\right) \\
/ \mathrm{HCO}_{3}\end{array}$ \\
\hline \multirow{3}{*}{ KS Earty } & Gradient & -1.58 & -0.32 & 0.81 \\
\hline & Intercept & 514 & 465 & 120 \\
\hline & $\mathrm{R}^{2}$ Value & 0.1359 & 0.0076 & 0.9109 \\
\hline \multirow{3}{*}{ KS Transition } & Gradient & 0.82 & 1.82 & 1.50 \\
\hline & Intercept & 247 & 227 & -115 \\
\hline & $\mathrm{R}^{2}$ Value & 0.4735 & 0.8585 & 0.8224 \\
\hline \multirow{3}{*}{ KS Late } & Gradient & 5.53 & 0.04 & 1.05 \\
\hline & Intercept & 114 & 109 & -5.69 \\
\hline & $R^{2}$ Value & 0.7634 & 0.8259 & 0.9927 \\
\hline \multirow{3}{*}{ LG Early } & Gradient & 0.95 & 1.92 & 1.52 \\
\hline & Intercept & 95.4 & 38.1 & -52.3 \\
\hline & $R^{2}$ Value & 0.6461 & 0.9354 & 0.8231 \\
\hline \multirow{3}{*}{ LG Late } & Gradient & 1.17 & 152 & 0.83 \\
\hline & Intercept & 80.2 & 38.8 & -7.57 \\
\hline & $\mathrm{R}^{2}$ Value & 0.4941 & 0.8586 & 0.768 \\
\hline
\end{tabular}

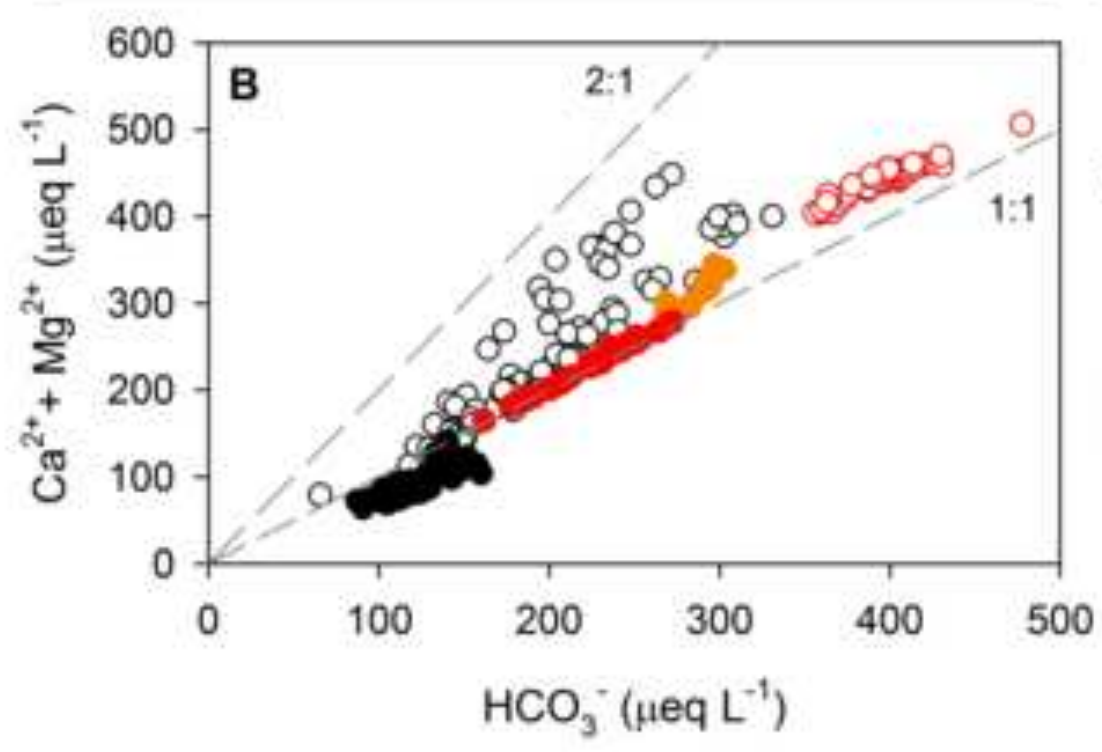

- KS Late - LG Early - LG Late KS Transition

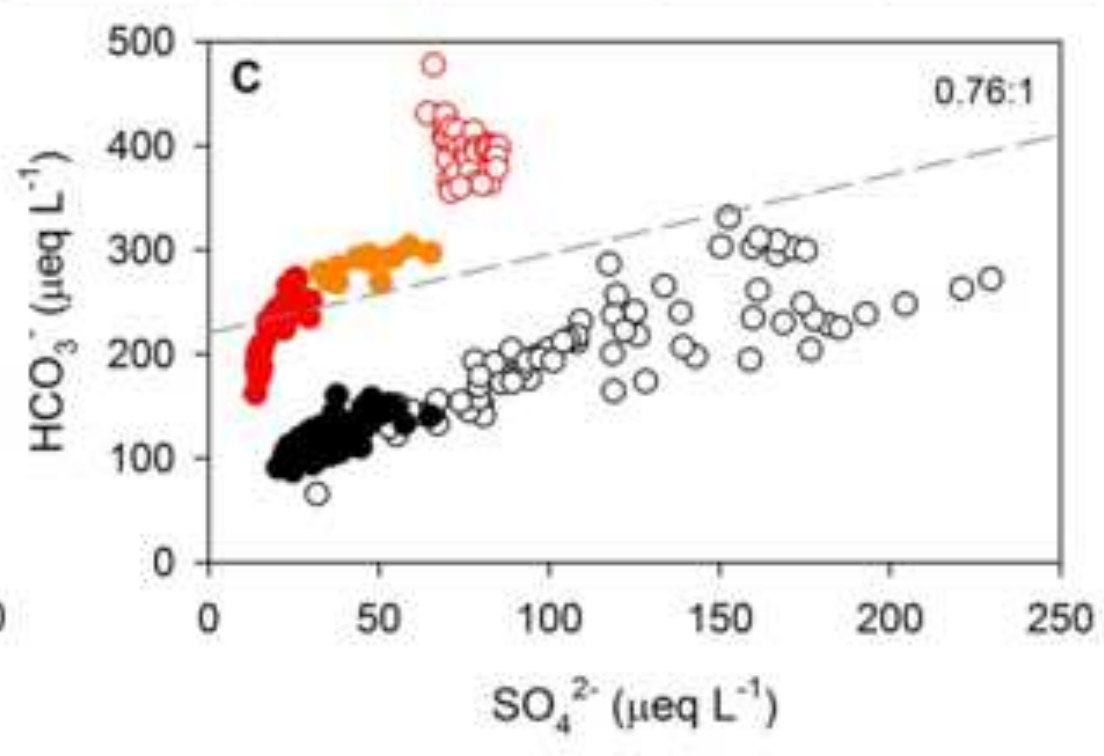



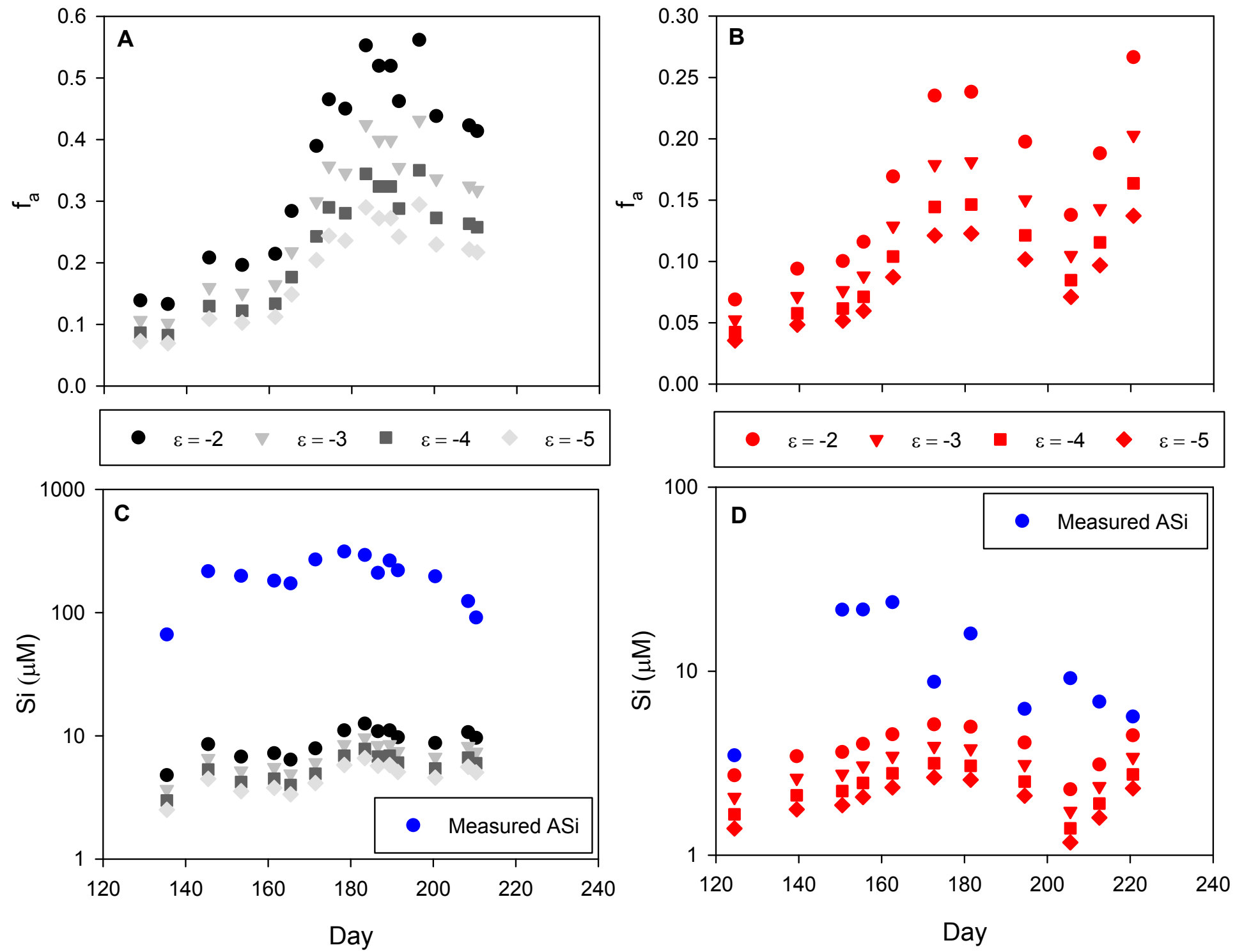


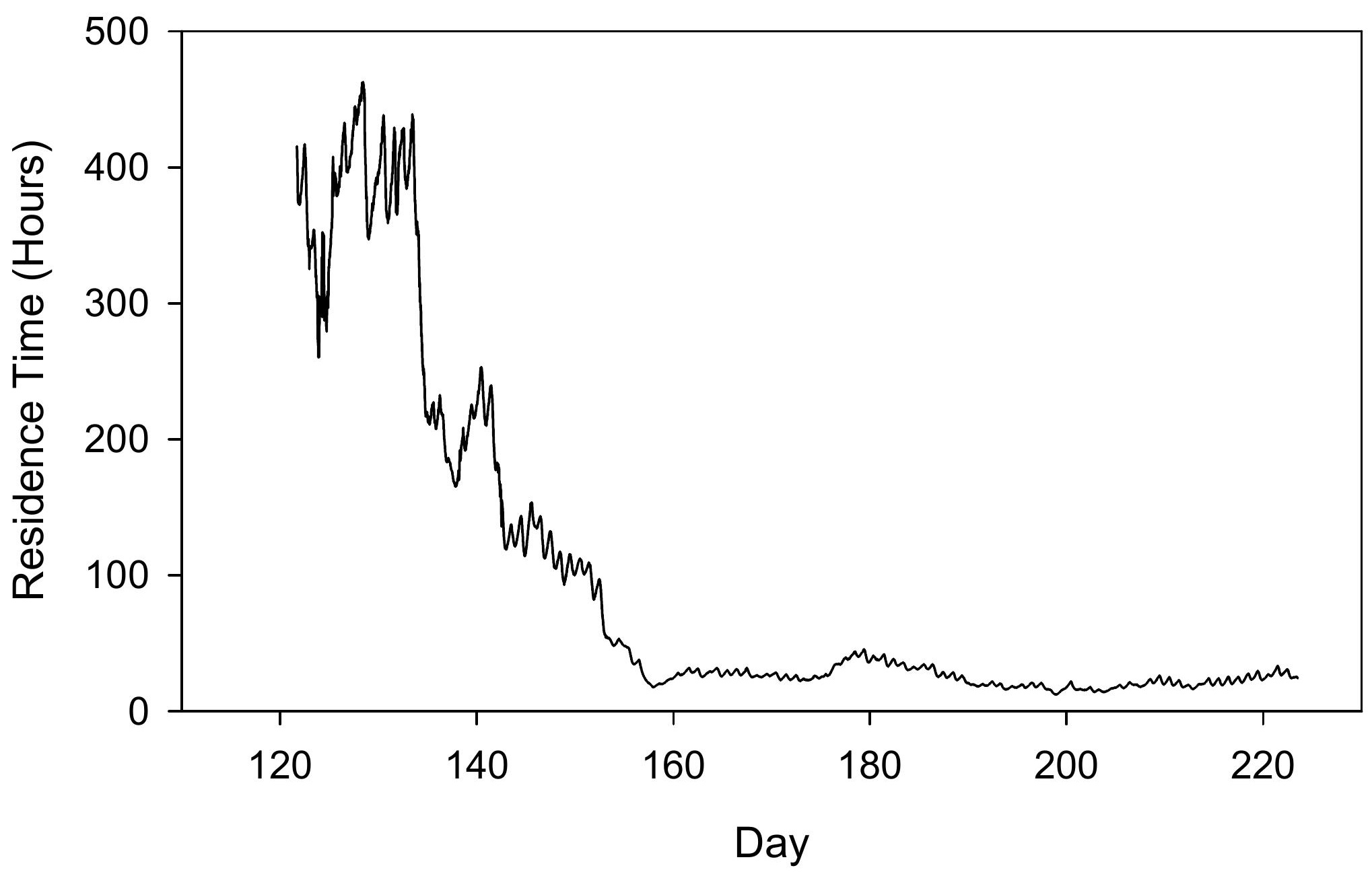




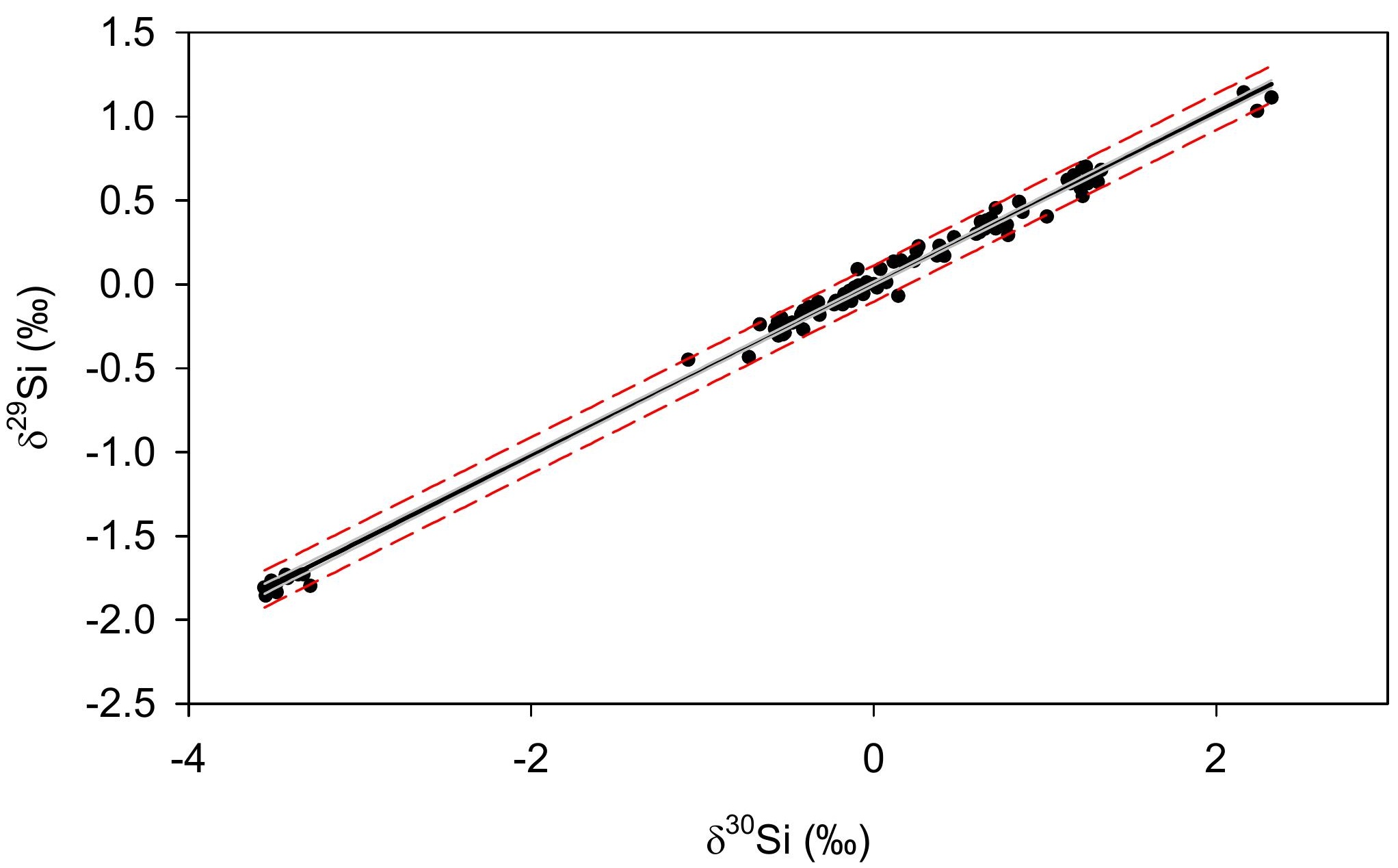




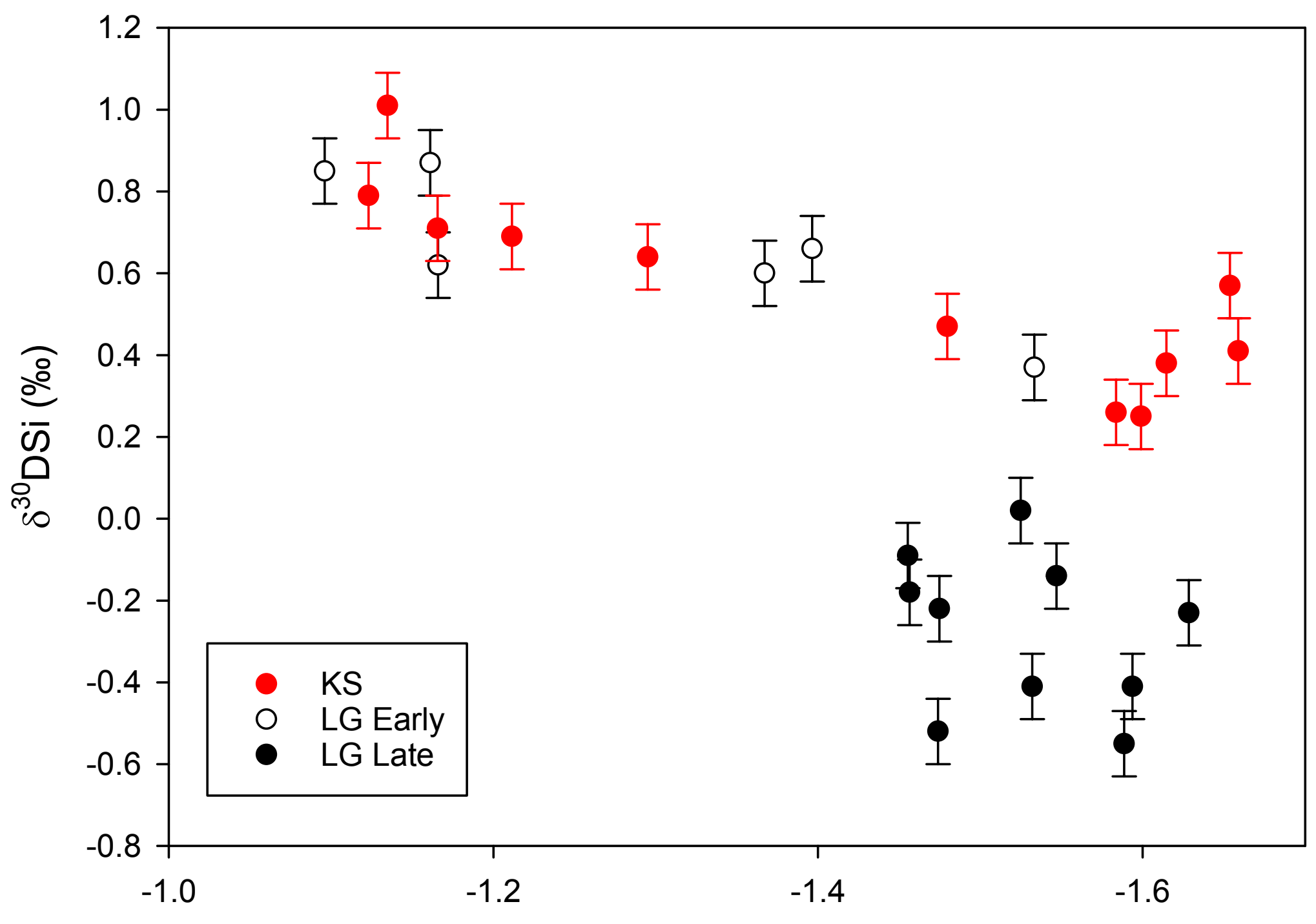

ASi Saturation Index 


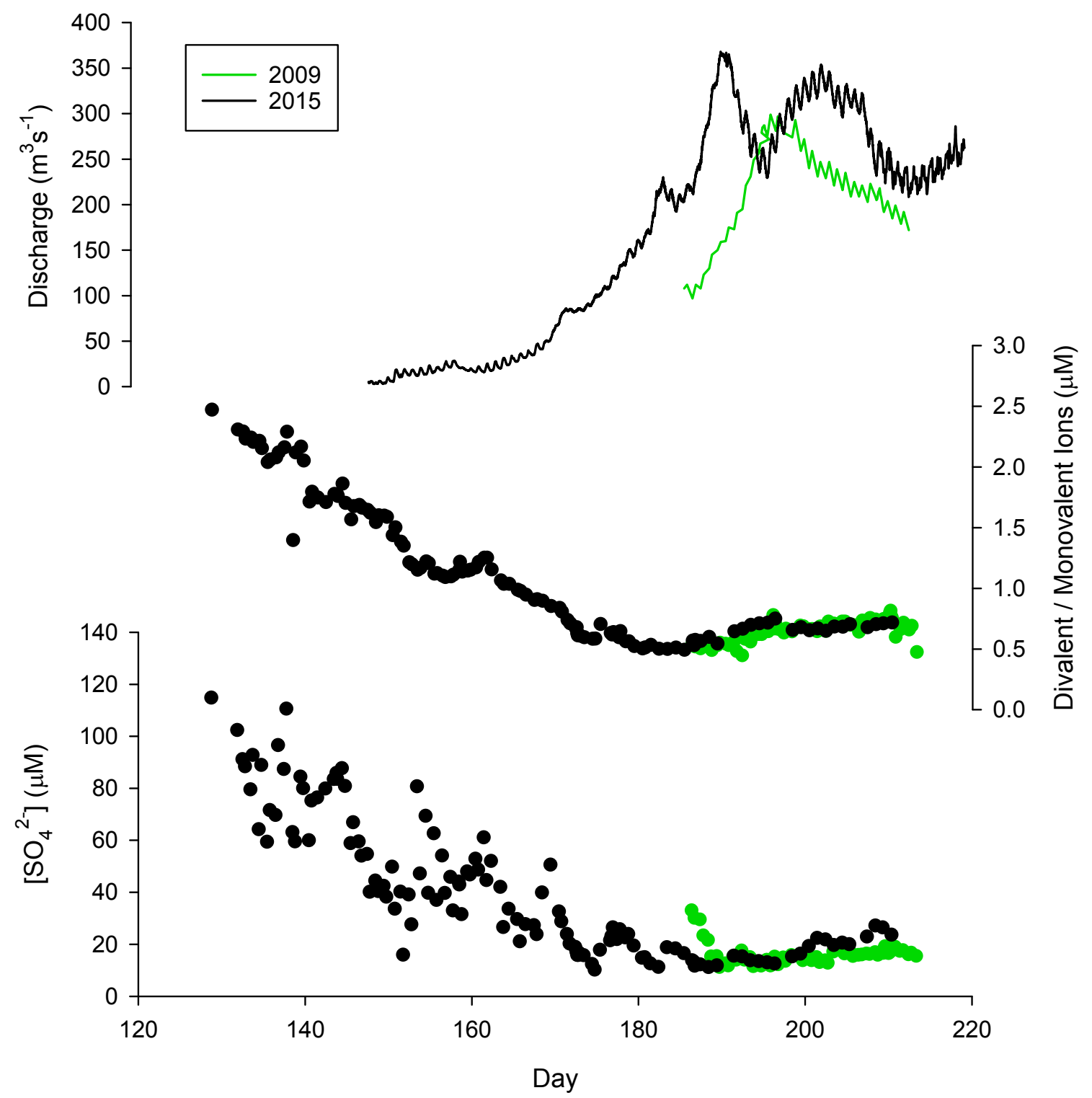


$\begin{array}{llll}\circ & \text { LG Early } & \text { KS Early } & \text { KS Late }\end{array}$

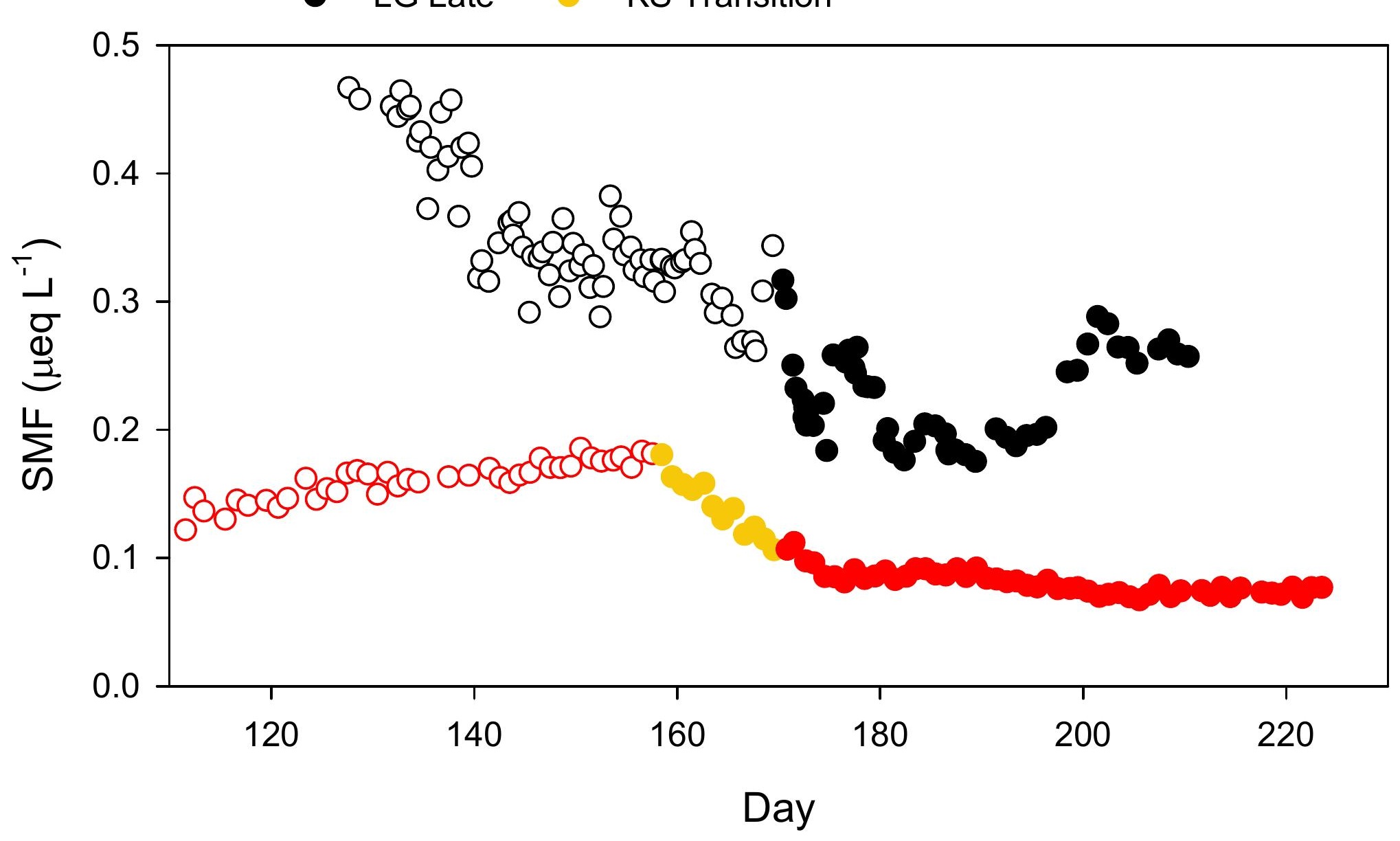



Equations
Click here t Clic

\author{
Click here to download Source or Other Companion File: Equations 1-7.doc
}

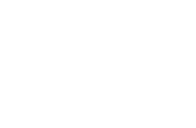

(1)

(1)

$\sqrt{10}$

(1)

(1)

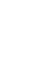

.

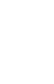

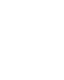

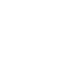

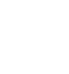
更

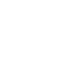

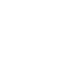
更

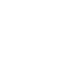

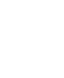

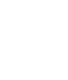

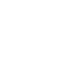

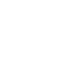

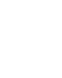

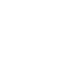

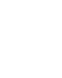

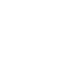

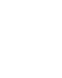

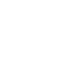
. 